\title{
An assessment of particulate organic carbon to thorium-234 ratios in the ocean and their impact on the application of ${ }^{234} \mathrm{Th}$ as a POC flux proxy
}

K.O. Buesseler ${ }^{\text {a,* }}$, C.R. Benitez-Nelson ${ }^{\text {b }}$, S.B. Moran ${ }^{\text {c }}$, A. Burd ${ }^{\text {d }}$, M. Charette ${ }^{\text {a }}$, J.K. Cochran ${ }^{\text {e }}$, L. Coppola ${ }^{\text {f }}$, N.S. Fisher ${ }^{\text {e }}$, S.W. Fowler ${ }^{\text {g,1 }}$, W.D. Gardner ${ }^{\text {h }}$, L.D. Guo ${ }^{\mathrm{i}}$, Ö. Gustafsson ${ }^{j}$, C. Lamborg ${ }^{\text {a }}$, P. Masque ${ }^{\text {k }}$, J.C. Miquel ${ }^{\text {g }}$, U. Passow ${ }^{1}$, P.H. Santschi ${ }^{\text {m, }}$, N. Savoye ${ }^{\mathrm{n}, 2}$, G. Stewart $^{\mathrm{e}}, \mathrm{T}_{\text {. Trull }}{ }^{\mathrm{O}}$

a Department of Marine Chemistry and Geochemistry, Woods Hole Oceanographic Institution, Woods Hole, MA 02543, USA

${ }^{\mathrm{b}}$ Department of Geological Sciences/Marine Science Program, University of South Carolina, Columbia, SC 29208, USA

${ }^{c}$ Graduate School of Oceanography, University of Rhode Island, Narragansett, RI 02882, USA

${ }^{\mathrm{d}}$ Department of Marine Sciences, University of Georgia, Athens, GA 30602, USA

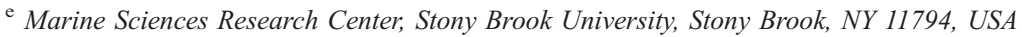

${ }^{\mathrm{f}}$ Swedish Museum of Natural History, Laboratory for Isotope Geology, 10405 Stockholm, Sweden

${ }^{g}$ Marine Environment Laboratory, International Atomic Energy Agency, MC 98000, Principality of Monaco

${ }^{\mathrm{h}}$ Department of Oceanography, Texas A\&M University, College Station, TX 77843, USA

${ }^{\mathrm{i}}$ International Arctic Research Center, University of Alaska Fairbanks, Fairbanks, AK 99775, USA

${ }^{\mathrm{j}}$ Stockholm University, Department of Applied Environmental Science, 10691 Stockholm, Sweden

${ }^{k}$ Institue de Ciencia I Tecnologia Ambientals, Univertsitat Atonoma de Barcelona, 08193 Bellaterra, Spain

${ }^{1}$ Alfred-Wegener-Institute for Marine and Polar Research, D-27570 Bremerhaven, Germany

${ }^{\mathrm{m}}$ Department of Oceanography and Marine Sciences, Texas A\&M University, Galveston, TX 77551, USA

${ }^{\mathrm{n}}$ Department of Analytical and Environmental Chemistry, Vrije Universiteit Brussels B-1050 Brussels, Belgium

- ACE CRC, University of Tasmania and CSIRO Marine Research, Hobart, Tasmania, Australia

Received 28 February 2005; accepted 10 October 2005

Available online 28 February 2006

\begin{abstract}
Thorium-234 is increasingly used as a tracer of ocean particle flux, primarily as a means to estimate particulate organic carbon export from the surface ocean. This requires determination of both the ${ }^{234} \mathrm{Th}$ activity distribution (in order to calculate ${ }^{234} \mathrm{Th}$ fluxes) and an estimate of the $\mathrm{C} /{ }^{234} \mathrm{Th}$ ratio on sinking particles, to empirically derive $\mathrm{C}$ fluxes. In reviewing $\mathrm{C} /{ }^{234} \mathrm{Th}$ variability, results obtained using a single sampling method show the most predictable behavior. For example, in most studies that employ in situ pumps to collect size fractionated particles, $\mathrm{C} /{ }^{234} \mathrm{Th}$ either increases or is relatively invariant with increasing particle size (size classes $>1$ to $100 \mathrm{~s} \mu \mathrm{m}$ ). Observations also suggest that $\mathrm{C} /{ }^{234} \mathrm{Th}$ decreases with depth and can vary significantly between regions (highest in blooms of large diatoms and highly productive coastal settings). Comparisons of C fluxes derived from ${ }^{234} \mathrm{Th}$ show good agreement with independent estimates of $\mathrm{C}$ flux, including mass balances of $\mathrm{C}$ and nutrients over appropriate space and time scales (within factors of 2-3). We recommend sampling for $\mathrm{C} /{ }^{234} \mathrm{Th}$ from a standard depth of $100 \mathrm{~m}$, or at least one depth below
\end{abstract}

\footnotetext{
* Corresponding author. Tel.: +1 508289 2309; fax: +1 5084572193.

E-mail address: kbuesseler@whoi.edu (K.O. Buesseler).

${ }^{1}$ Retired from IAEA-MEL. Present address: 8, Allee des Orangers, 06320 Cap d'Ail, France.

${ }^{2}$ Present address: EPOC Station Marine d'Arcachon, 33120 Arcachon, France.
} 
the mixed layer using either large volume size fractionated filtration to capture the rarer large particles, or a sediment trap or other device to collect sinking particles. We also recommend collection of multiple ${ }^{234} \mathrm{Th}$ profiles and $\mathrm{C} /{ }^{234} \mathrm{Th}$ samples during the course of longer observation periods to better sample temporal variations in both ${ }^{234} \mathrm{Th}$ flux and the characteristic of sinking particles. We are encouraged by new technologies which are optimized to more reliably sample truly settling particles, and expect the utility of this tracer to increase, not just for upper ocean $\mathrm{C}$ fluxes but for other elements and processes deeper in the water column. (C) 2006 Elsevier B.V. All rights reserved.

\section{Introduction}

Since the first reported measurements of thorium$234\left({ }^{234} \mathrm{Th}\right)$ in the ocean (Bhat et al., 1969), decreases in ${ }^{234} \mathrm{Th}$ activities between open ocean and coastal waters indicated that ${ }^{234} \mathrm{Th}$ activity distributions were strongly influenced by the marine particle cycle. This prompted the use of ${ }^{234} \mathrm{Th}$ as a new in situ tracer of oceanic "scavenging", a term used to describe the complex processes related to the association of particle reactive elements with particle surfaces and their removal in the oceans (Goldberg, 1954). Using simple activity balance equations (see review by Savoye et al., 2006-this volume), the ratio of the particle reactive radionuclide ${ }^{234} \mathrm{Th}$ (half life $=24.1$ days) to its soluble and long lived parent, ${ }^{238} \mathrm{U}$, can be used to quantify the rate of uptake of ${ }^{234} \mathrm{Th}$ onto particles and their export flux out of the surface ocean. A larger disequilibrium in total activities $\left({ }^{234} \mathrm{Th}:{ }^{238} \mathrm{U}\right.$ activity ratios $\left.<1\right)$ reflects a higher export flux.

The focus of this review is on the application of ${ }^{234} \mathrm{Th}$ as a tracer of the export flux of particulate organic carbon (POC) from surface waters. A central question is: how can one use the rates of ${ }^{234} \mathrm{Th}$ removal to determine the flux of carbon associated with sinking particles? Early studies showed a positive correlation between the ${ }^{234} \mathrm{Th}:{ }^{238} \mathrm{U}$ disequilibria and biological activity in the upper ocean of the eastern north Pacific, which was attributed to attachment and removal of ${ }^{234} \mathrm{Th}$ on sinking biological particulate matter (Coale and Bruland, 1985, 1987). Based upon these correlations, it was suggested that one might be able to use the total residence time of particulate ${ }^{234} \mathrm{Th}$ to estimate the flux of POC (Eppley, 1989). However, this approach was not pursued since the residence times of particulate ${ }^{234} \mathrm{Th}$ and POC are unlikely to be the same, due to their different rates of recycling in the surface ocean (Murray et al., 1989).

A more direct approach for using ${ }^{234} \mathrm{Th}$ as a particle flux proxy is to multiply the ${ }^{234} \mathrm{Th}$ flux (derived from ${ }^{234} \mathrm{Th}:{ }^{238} \mathrm{U}$ ) by its ratio to other elements on sinking particles; i.e., for carbon, Flux $\mathrm{C}={ }^{234} \mathrm{Th}$ flux $\times \mathrm{C} /{ }^{234} \mathrm{Th}$ on sinking particles (Fig. 1a). The flux of $\mathrm{C}$ would be doubled, if the $\mathrm{C} /{ }^{234} \mathrm{Th}$ ratio of particles sinking to depth was twice as high for the same Th flux or ${ }^{234} \mathrm{Th}:{ }^{238} \mathrm{U}$ disequilibria (Fig. 1b). On the other hand, if the ${ }^{234}$ Th flux was reduced by half then also (Fig. 1c), there would be a corresponding decrease in ${ }^{234} \mathrm{Th}$ on sinking particles by a factor of two, but the C flux would remain the same relative to our initial example.

This empirical method, which we term here the ${ }^{234} \mathrm{Th}$ flux approach, was first formalized in a study of particle cycling and organic carbon export associated with the spring bloom in the North Atlantic (Buesseler et al., 1992), though the concept was applied in at least one much earlier study in the North Pacific (Tsunogai and Minagawa, 1976). After its initial application to POC and particulate organic nitrogen (PON) fluxes, this approach was expanded to include other elemental fluxes, such as particulate inorganic carbon (Bacon et al., 1996), PAHs (polycyclic aromatic hydrocarbons; Gustafsson et al., 1997a), PCBs (polychlorinated biphe-

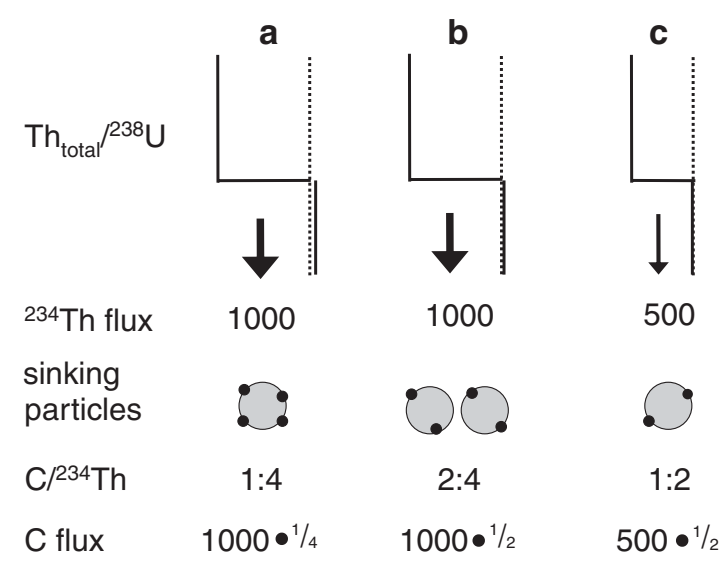

Fig. 1. Schematic of the ${ }^{234}$ Th flux approach. Three scenarios are shown for differing conditions of ${ }^{234} \mathrm{Th}:{ }^{238} \mathrm{U}$ disequilibria, ${ }^{234} \mathrm{Th}$ flux, sinking particle $\mathrm{C} /{ }^{234} \mathrm{Th}$ and the impact on calculated $\mathrm{C}$ flux. The magnitude of ${ }^{234} \mathrm{Th}$ flux is proportional to the ${ }^{234} \mathrm{Th}:{ }^{238} \mathrm{U}$ activity ratio (here $<1$ in surface waters, where ${ }^{234} \mathrm{Th}$ solid line $<{ }^{238} \mathrm{U}$ dotted line). In Panel a, the ${ }^{234} \mathrm{Th}$ flux of 1000 and a sinking particle $\mathrm{C} /{ }^{234} \mathrm{Th}$ ratio of $1 / 4$ results in a calculated POC flux of 250 . Panel $b$ shows the impact of a doubling of the $\mathrm{C} /{ }^{234} \mathrm{Th}$ ratio for the same ${ }^{234} \mathrm{Th}$ flux $(\mathrm{C}$ flux doubles). Panel c shows how a 50\% reduction in Th flux for the same $\mathrm{C} /{ }^{234} \mathrm{Th}$ ratio as in b results in a decrease in C flux by $50 \%$. Units are not needed in these examples, but are commonly $\mathrm{dpm} \mathrm{m}^{-2}$ $\mathrm{d}^{-1}$ for ${ }^{234} \mathrm{Th}$ flux, $\mu \mathrm{mol} \mathrm{dpm}^{-1}$ for $\mathrm{C} /{ }^{234} \mathrm{Th}$, and $\mathrm{C}$ flux in mmol $\mathrm{m}^{-2} \mathrm{~d}^{-1}$. One $\mathrm{dpm}=1 / 60$ th Bq. 
nyls; Gustafsson et al., 1997b), biogenic silica (Buesseler et al., 2001; Rutgers van der Loeff et al., 2002) and trace metals (Gustafsson et al., 2000a; Weinstein and Moran, in review). Here we emphasize the use of ${ }^{234} \mathrm{Th}$ as a POC flux proxy. We also emphasize applications of ${ }^{234} \mathrm{Th}$ to processes in the upper ocean where ${ }^{234} \mathrm{Th}:{ }^{238} \mathrm{U}$ disequilibrium is common because particle fluxes are rapid relative to thorium's in situ production rate.

The principal limitations of the ${ }^{234} \mathrm{Th}$ flux approach are our ability to model ${ }^{234} \mathrm{Th}$ export on sinking particles (discussed extensively in Savoye et al., 2006-this volume) and how accurately we can characterize the ratio of POC to ${ }^{234} \mathrm{Th}$ (hereafter $\mathrm{C} /{ }^{234} \mathrm{Th}$ ) on sinking particles. Beginning with the earliest applications, differences in $\mathrm{C} /{ }^{234} \mathrm{Th}$ were found between samples and between studies depending on the different particle collection devices used, such as sediment traps, filtration from ocean sample bottles, or in situ filtration using pumps and size fractionated particle sampling (Buesseler et al., 1995; Murray et al., 1996). Regional differences and changes with depth and season were also evident. Why does this occur?

The goal of this paper is to provide an assessment of $\mathrm{C} /{ }^{234} \mathrm{Th}$ variability in the upper ocean and to discuss potential causes thereof. We begin with a general discussion of possible geochemical and biological controls on the $\mathrm{C} /{ }^{234} \mathrm{Th}$ ratio of particles, to serve as a foundation for understanding and perhaps predicting $\mathrm{C} /{ }^{234} \mathrm{Th}$ ratios. We will consider how well sinking particles are represented by, or are variable within the particulate samples that are used to determine $\mathrm{C} /{ }^{234} \mathrm{Th}$ in a given study. One way to address this question is by investigating variability in $\mathrm{C} /{ }^{234} \mathrm{Th}$ vs. particle size, sampling depth, season, region, and sampling method. Another is to compare ${ }^{234} \mathrm{Th}$-derived fluxes with independent estimates of $\mathrm{C}$ cycling, such as new production, primary production and $\mathrm{C}$ or nutrient mass balances. None of these independent methods, including direct estimates of flux using sediment traps, are without their own biases and assumptions. We are encouraged by agreement between the ${ }^{234} \mathrm{Th}$ flux approach and multiple methods where appropriate comparisons can be made. We present technologies that are just beginning to be used to better sample sinking particles and thus obtain a more accurate $\mathrm{C} /{ }^{234} \mathrm{Th}$ ratio on both bulk and specific classes of sinking particles. Finally, as a community review article, we provide recommendations to further our understanding of processes responsible for $\mathrm{C} /{ }^{234} \mathrm{Th}$ variability, and discuss standardized methodologies to improve our use of ${ }^{234} \mathrm{Th}$ as a particle flux proxy in ocean sciences.

\section{Overview of processes controlling the $\mathrm{C} /{ }^{234} \mathrm{Th}$ ratio of marine particles}

Despite over a decade using ${ }^{234} \mathrm{Th}$ and $\mathrm{C} /{ }^{234} \mathrm{Th}$ ratios to determine export fluxes of POC, there is no single process or model that can be invoked to explain how particulate $\mathrm{C} /{ }^{234} \mathrm{Th}$ ratios vary with time, depth, particle type, size, or sinking velocity. Various methods and studies have shown the $\mathrm{C} /{ }^{234} \mathrm{Th}$ ratio to vary from 1 to $>100 \mu \mathrm{mol} \mathrm{dpm}{ }^{-1}$ (all references to $C{ }^{234}$ Th will be

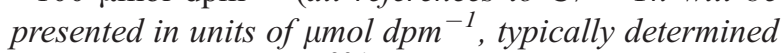
for total organic $C$ and ${ }^{234}$ Th decay corrected to the time of sampling; one dpm =1 disintegration per minute $=1$ $60 \mathrm{~Bq}=1 / 60$ disintegration per second). There is continued discussion regarding the significance of this variability for the accuracy of the ${ }^{234} \mathrm{Th}$ flux approach (e.g., Buesseler, 1998; Moran et al., 2003, 2004; BenitezNelson and Charette, 2004). For the application of ${ }^{234} \mathrm{Th}$ as a POC flux proxy, we do not need to know the $\mathrm{C} /{ }^{234} \mathrm{Th}$ ratio on all particles, just the ones sinking out of surface waters. Hence, site specific variability at depth is most important in the application of this method.

To a first order, thorium reaches chemical equilibrium or quasi-equilibrium with respect to sorption to particle surface sites (see review by Santschi et al., 2006-this volume), whereas C content varies as a function of particle volume and/or composition. This relationship of ${ }^{234} \mathrm{Th}$ with surface sites and $\mathrm{C}$ with particle volume leads to an initial prediction that $\mathrm{C} /{ }^{234} \mathrm{Th}$ should increase on larger particles due to increasing volume:surface area ( $V$ :SA) (Fig. 2). All $\mathrm{C} /{ }^{234} \mathrm{Th}$ versus size relationships that rely on $V$ : $\mathrm{SA}$ are sensitive to particle shape, size and morphology. Cell-specific changes in $V$ : SA during growth (Snoeijs et al., 2002) or seasonal progression of a biological community, that includes bacteria up to large cells and aggregates, impact the average $V$ :SA relationship and would thus influence the $\mathrm{C} /{ }^{234} \mathrm{Th}$ ratio. Conceptually, a change in $\mathrm{C} /{ }^{234} \mathrm{Th}$ vs. size is important because sinking velocities are thought to be related to particle size and excess density (Smayda, 1970; Asper, 1987; Alldredge and Gotschalk, 1989). This can be incorporated into models with ocean particle settling parameterized using modified Stokes settling velocities (Jackson, 1995; Burd and Jackson, 1997).

There are other processes however that can impact $\mathrm{C} /{ }^{234}$ Th (Fig. 2). For example, rapid abiotic aggregation of small particles into larger ones would leave the $\mathrm{C} /{ }^{234} \mathrm{Th}$ relationship vs. size unchanged. The rate of aggregation varies as a function of particle size, concentration, and stickiness, and much attention has been paid to TEP (transparent exopolymers) or other 


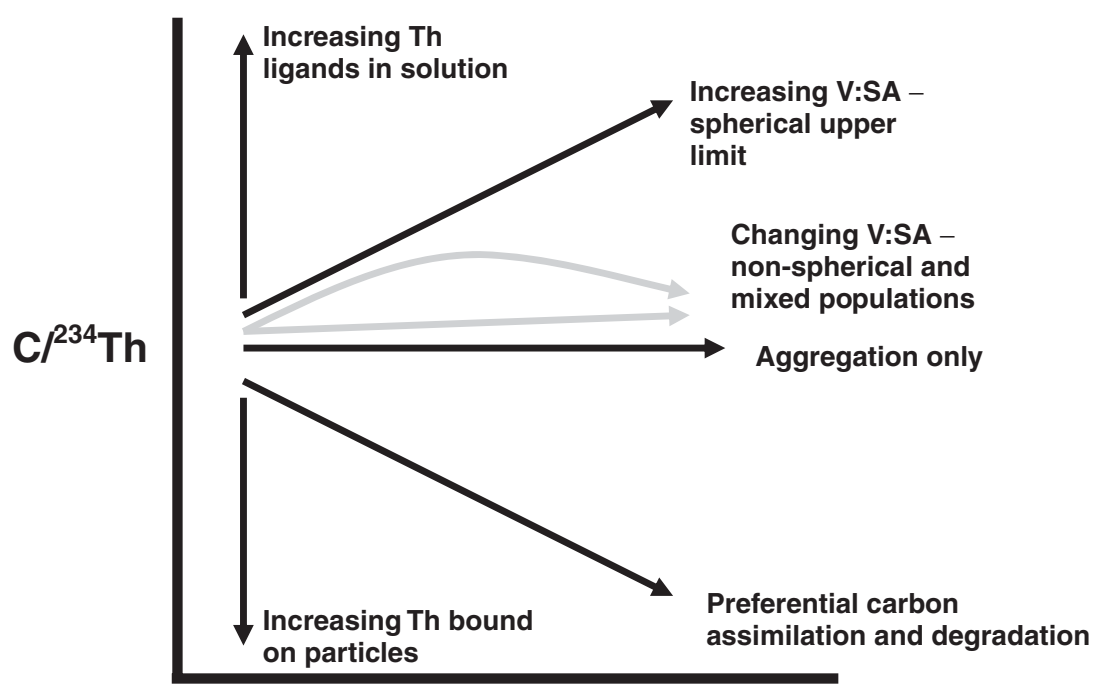

Size

Fig. 2. A conceptual view of the impact of various biogeochemical processes on $\mathrm{C} /{ }^{234} \mathrm{Th}$ ratios and particle sizes. As thorium associates principally with surface sorption sites and organic carbon is dominated by pools internal to cells, one might expect $\mathrm{C} /{ }^{234} \mathrm{Th}$ ratios to increase as particle size increases, with the volume to surface area $(V: \mathrm{SA})$ ratios of spheres representing the upper limit for the relationship (all other cell/particle shapes have lower $V$ :SA trends with size). Particle sizes in real marine systems tend to increase as a result of complex biological processes, however, including aggregation of small, neutrally buoyant cells into larger sinking particles and the generation of fecal material. Rapid aggregation of small particles alone without loss of mass would probably yield no change in $V$ : SA ratios and hence no change in $\mathrm{C} /{ }^{234} \mathrm{Th}$, while consumption of particles by zooplankton would result in preferential assimilation losses of carbon and hence a decrease in $\mathrm{C} /{ }^{234} \mathrm{Th}$ ratios in larger fecal pellets. Processes that affect the Th side of the ratio (Th speciation), are not likely to be linked to particle size in a general way. These include increases in dissolved and particulate Th-binding ligands or sorption sites, which would increase or decrease $\mathrm{C} /{ }^{234} \mathrm{Th}$ ratios, respectively.

natural "glues" that are produced under conditions of phytoplankton stress, and hence may trigger the onset of higher export of diatom aggregates (Passow et al., 1994; Passow and Alldredge, 1995; Passow, 2002).

Conversely, a decrease in the $\mathrm{C} /{ }^{234} \mathrm{Th}$ ratio with size is expected if there are preferential $\mathrm{C}$ loss terms, such as degradation or assimilation of $\mathrm{C}$. One way to think of this process is to consider $\mathrm{C}$ assimilation rates between trophic levels, which predict a decreasing $\mathrm{C}$ content per unit volume between phytoplankton (generally small) and zooplankton fecal matter (usually larger and rapidly sinking). There is evidence of high ${ }^{234} \mathrm{Th}$ activities in fecal material relative to C or mass (Coale, 1990) most likely due to preferential assimilation of cytoplasmic C. If the particle spectrum is characterized by abundant fecal material, $\mathrm{C} /{ }^{234} \mathrm{Th}$ would be lower on the larger size class pellets vs. small cells (Fig. 2).

In coastal settings, one would also have to consider the abundance of detrital materials derived from land or resuspended from bottom sediments. These materials would presumably have a lower $\mathrm{C}$ content than fresh plankton and these might have higher or lower ${ }^{234} \mathrm{Th}$ depending upon the balance between ${ }^{234} \mathrm{Th}$ scavenging and decay.
We have thus far assumed a constant binding capacity for all particle surfaces. If the number of surface sites or affinity for ${ }^{234} \mathrm{Th}$ changes with particle size or type this would impact $\mathrm{C} /{ }^{234} \mathrm{Th}$ ratios as well (Lee et al., 1993). For example, it has been proposed that changes in solution chemistry associated with complexation of ${ }^{234} \mathrm{Th}$ by natural acid polysaccharide (APS)rich TEP ligands (e.g., Guo et al., 2002a; Hung et al., 2004; Santschi et al., 2003) alters the exchange of ${ }^{234} \mathrm{Th}$ (relative to POC) with the surrounding particle regime. While distribution coefficients of ${ }^{234} \mathrm{Th}$ for different inorganic particle types are on the order of $10^{3}-10^{6}$, $\mathrm{L} / \mathrm{kg}$, affinity for APS ligands, which are part of the polysaccharide fraction, is more than two orders of magnitude higher for colloidal size classes $(1 \mathrm{kDa}$ to $0.2 \mu \mathrm{m}$; Guo et al., 2002b; Quigley et al., 2002) when expressed as $\mathrm{L} / \mathrm{kg}$ polysaccharides, with similar abundance of polysaccharides and organic sorbents. Thus, the $\mathrm{C} /{ }^{234}$ Th ratio would decrease when APS is ubiquitous. A similar occurrence happens when inorganic particles poor in organic carbon, are abundant. This implies that changes in particle type and Th speciation can alter the $\mathrm{C} /{ }^{234} \mathrm{Th}$ ratio of suspended and sinking particles independent of other mechanisms. The speciation of ${ }^{234} \mathrm{Th}$ in seawater is reviewed in detail in a 
companion paper in this issue (Santschi et al., 2006-this volume).

For the successful application of the Th flux approach, one also needs to consider the temporal and spatial scales of scavenging and flux processes in the ocean. The in situ ${ }^{234} \mathrm{Th}:{ }^{238} \mathrm{U}$ disequilibrium is an integrated measurement of flux over several days to weeks prior to sampling, while the measurements used to characterize $\mathrm{C} /{ }^{234} \mathrm{Th}$ on sinking particles are often single points in space and time. In short, today's particles may not be characteristic of yesterday's flux. Ideally, one would measure total ${ }^{234} \mathrm{Th}$ activities over time and space to determine the ${ }^{234} \mathrm{Th}$ flux out of a given water parcel, and use similar coverage for the particulate $\mathrm{C} /{ }^{234} \mathrm{Th}$ ratio of sinking particles at the base of the same water parcel, to accurately determine the flux of POC (see Savoye et al., 2006-this volume). Rarely is this level of sampling achieved, and there are practical limitations in the extent of sampling on all scales of time and space. Single profiles of total ${ }^{234} \mathrm{Th}$ are often used to predict the export flux using 1-D steady state models, and one or a few particulate samples are analyzed for $\mathrm{C} /{ }^{234} \mathrm{Th}$. For the ${ }^{234} \mathrm{Th}$ flux approach to hold, we need a representative sampling of sinking particles. One would want to know $\mathrm{C} /{ }^{234} \mathrm{Th}$ for every class of sinking particles as a function of the percent of $\mathrm{C}$ carried by each particle type, i.e., a flux weighted average of $\mathrm{C} /{ }^{234} \mathrm{Th}$. The method is inaccurate if there is some fraction of the sinking flux that has both different $\mathrm{C} /{ }^{234} \mathrm{Th}$, and if these unsampled particles are responsible for a significant fraction of the total $\mathrm{C}$ flux.

In the following sections, we limit our discussion to how $\mathrm{C} /{ }^{234} \mathrm{Th}$ variations with size, depth, season, region, and sampling device may be explained by processes such as growth, assimilation and aggregation (e.g., Fig. 2). Because we are concerned with the application of ${ }^{234} \mathrm{Th}$ as a proxy for sinking particles, attention is devoted to filterable particles of size $\approx 1 \mu \mathrm{m}$ and larger, which are thought to be the main contributers to vertical export flux.

\section{3. $\mathrm{C} /{ }^{234} \mathrm{Th}$ versus particle size}

Marine particles come in many different shapes and sizes, with the more abundant smaller particles being considered less likely to sink due to their smaller size (though density will also play an important role). Based upon models and measurements, it is the rarer, large cells, fecal pellets, and marine snow aggregates that are thought to dominate particle export (e.g., Fowler and Knauer, 1986). For this reason, earlier ${ }^{234} \mathrm{Th}$ studies used sequential filtration methods to separate large and small particles, following the lead of Bishop et al. (1978) and others. By convention, particles were most often separated using a $53 \mu \mathrm{m}$ diameter or other large pore sized screen followed in series by a $0.5-1 \mu \mathrm{m}$ filter, thus operationally defining large $\geq 53 \mu \mathrm{m}$ and small particles $(1-53 \mu \mathrm{m})$ that were later analyzed for both $\mathrm{C}$ and ${ }^{234} \mathrm{Th}$. In most applications, the $\mathrm{C} /{ }^{234} \mathrm{Th}$ ratio on the larger size classes was assumed to approximate the ratio on sinking particles, and hence, could be used to convert ${ }^{234} \mathrm{Th}$ fluxes into POC export.

Some of the first large scale applications of the ${ }^{234} \mathrm{Th}$ flux approach were made during the 1992 U.S. JGOFS Study in the equatorial Pacific. In this region, measurements of $\mathrm{C} /{ }^{234} \mathrm{Th}$ showed a factor of 2 to 4 lower $\mathrm{C} /{ }^{234} \mathrm{Th}$ on the $\geq 53 \mu \mathrm{m}$ versus the $1-53 \mu \mathrm{m}$ fractions in two studies (Bacon et al., 1996; Buesseler et al., 1995), and similar $\mathrm{C} /{ }^{234} \mathrm{Th}$ ratios vs. size in a third (Dunne et al., 1997). The equatorial Pacific study area is a region characterized by efficient recycling of nutrients and $\mathrm{C}$, and maintains a community structure dominated by small picoplankton and flagellate grazers (Landry et al., 1997). These abundant, biologicallyderived small particles have some of the lowest particulate $\mathrm{C} /{ }^{234} \mathrm{Th}$ ratios that have been measured (Buesseler et al., 1998).

Other data sets followed that measured $\mathrm{C} /{ }^{234} \mathrm{Th}$ in colloidal size classes using cross flow filtration (e.g., Moran and Buesseler, 1992; Guo et al., 1997; replotted in Santschi et al., 2006-this volume) or small volume filtration for the smaller particle size classes. The ratios in this very small sub-micron size range seemed to fit a pattern of decreasing $\mathrm{C} /{ }^{234} \mathrm{Th}$ with particle size (Burd et al., 2000; Guo et al., 1997, 2002a). A model that included uptake of Th by small and abundant colloids and production of larger aggregates using a particle aggregation model, predicted a decrease in $\mathrm{C} /{ }^{234} \mathrm{Th}$ with size for the smallest size classes and relatively invariant or slowly decreasing $\mathrm{C} /{ }^{234} \mathrm{Th}$ in the $1-100 \mu \mathrm{m}$ range (Burd et al., 2000).

A number of other studies, however, seem to contradict this earlier trend (Table 1). This is due in part to differences in collection method, which include comparisons between cross flow filtration, large volume samples filtered with in situ pumps, small volume samples filtered out of bottles, and POC and particulate ${ }^{234} \mathrm{Th}$ collected on different filter types. The challenges of collecting unbiased or truly representative marine particle samples have been known for some time. These challenges apply to studies of the smallest colloids isolated via cross flow filtration (e.g., Buesseler et al., 1996) to those of larger particles where differences 
Table 1

Summary of $\mathrm{C} /{ }^{234} \mathrm{Th}$ vs. particle size $(>0.7$ to $1 \mu \mathrm{m}$ and collected using a single sampling device)

\begin{tabular}{|c|c|c|c|c|}
\hline Location & $\begin{array}{l}\mathrm{C} / \mathrm{Th} \text { trend with } \\
\text { increasing particle size }\end{array}$ & Collection device & Reference & Comment \\
\hline Eq. Pacific & Decrease & In situ pump & Buesseler et al., 1995 & $\begin{array}{l}1 \text { and } 53 \mu \mathrm{m} \text {; average of all data, } \\
\text { mostly } 0-100 \mathrm{~m}\end{array}$ \\
\hline Eq. Pacific & Decrease & In situ pump & Bacon et al., 1996 & 1 and $53 \mu \mathrm{m}$ \\
\hline Eq. Pacific & No change & MULVFS & Dunne et al., 1997 & $\begin{array}{l}1 \text { and } 53 \mu \mathrm{m} \text {; Multi Unit Large Volume } \\
\text { Filtration System-J. Bishop }\end{array}$ \\
\hline Arabian Sea & Increase & In situ pump & Buesseler et al., 1998 & 1 and $53 \mu \mathrm{m}$. \\
\hline Mid Atlantic & Increase & In situ pump & Charette and Moran, 1999 & 0.7 and $53 \mu \mathrm{m}$ \\
\hline Ross Sea & Increase & In situ pump & Cochran et al., 2000 & $\begin{array}{l}1 \text { and } 70 \mu \mathrm{m} \text {; large differences }(>10 \times) \text { esp. in } \\
\text { surface; }>70 \mu \mathrm{m} \text { w/in factor of } 2 \text { of traps }\end{array}$ \\
\hline So. Ocean AESOPS & No change & In situ pump & Buesseler et al., 2001 & 1 and $70 \mu \mathrm{m}(70 \mu \mathrm{m} / \mathrm{QMA}=1.1 \pm 0.5)$ \\
\hline Hawaii, HOT & Increase & In situ pump & Benitez-Nelson et al., 2001 & $\begin{array}{l}1,10 \text { and } 53 \mu \mathrm{m} \text { at } 150 \mathrm{~m} \text { on } 5 \text { cruises } \\
\text { Oct. } 1999-\text { March } 2000\end{array}$ \\
\hline Gulf of Mexico & Decrease & In situ pump & $\begin{array}{l}\text { Guo et al., 2002a; } \\
\text { Hung et al., } 2004\end{array}$ & $\begin{array}{l}1,10 \text { and } 53 \mu \mathrm{m} \text {. These data differ from others } \\
\text { in this Table as while samples are collected } \\
\text { with one pump, different filters were used } \\
\text { and analyzed for } \mathrm{C} \text { (flat membranes/screens) } \\
\text { and }{ }^{234} \mathrm{Th} \text { (filter cartridges) }\end{array}$ \\
\hline Labrador Sea & Increase & In situ pump & Moran et al., 2003 & 10 and $53 \mu \mathrm{m}$ \\
\hline SOIREE So. Ocean & Increase/no change & In situ pump/hose & $\begin{array}{l}\text { Charette, Buesseler, } \\
\text { Trull, unpub }\end{array}$ & $\begin{array}{l}5 \text { size classes: } 1,5,20,70,210 \mu \mathrm{m} \text {; } \\
\text { pump described in (Trull and Armand, 2001) }\end{array}$ \\
\hline CLIVAR So. Ocean & Increase & In situ pump/hose & $\begin{array}{l}\text { Savoye, Trull, Buesseler, } \\
\text { unpub. }\end{array}$ & $\begin{array}{l}5 \text { size classes: } 1,5,20,53,210 \mu \mathrm{m} \text {; } \\
\text { pump described in (Trull and Armand, 2001) }\end{array}$ \\
\hline Bermuda, BATS & No change & In situ pump & $\begin{array}{l}\text { Buesseler et al., unpub. } \\
\text { in this form }\end{array}$ & 1 and $70 \mu \mathrm{m} @ 150 \mathrm{~m}$ \\
\hline South Aegean Sea & No change & In situ pump & Moran et al., unpub. & $\begin{array}{l}5 \text { size classes: } 10,20,53,70 \text { and } 100 \mu \mathrm{m} \\
\text { collected at } 50,75,100,150 \text { and } 300 \mathrm{~m} \text { depth }\end{array}$ \\
\hline Tyrrhenian Sea & No change & In situ pump & Speicher et al., unpub. & $\begin{array}{l}3 \text { size classes: } 10,53 \text { and } 100 \mu \mathrm{m} \text { collected } \\
\text { within upper } 200 \mathrm{~m}\end{array}$ \\
\hline
\end{tabular}

in POC concentrations between bottle filtration and in situ pumps have been documented (Moran et al., 1999; Gardner et al., 2003; Liu et al., 2005). Differences in $\mathrm{C} /{ }^{234} \mathrm{Th}$ as a function of sampling method will be discussed separately below. We contend that with regard to $\mathrm{C} /{ }^{234} \mathrm{Th}$ versus size relationships, those data collected using a single collection method are the most likely to demonstrate $\mathrm{C} /{ }^{234} \mathrm{Th}$ patterns that can be reliably interpreted. There is also a danger using one method or filter for POC and a different one for particulate ${ }^{234} \mathrm{Th}$, because the ratio may be influenced as much by operational sampling biases, as by true variability among different particle size classes.

If we restrict our $\mathrm{C} /{ }^{234} \mathrm{Th}$ analysis to size fractionated particulate data $>0.7$ to $1 \mu \mathrm{m}$ obtained using a single collection method, i.e., in situ pumps (since bottle filtration does not process sufficient volume for the analyses of ${ }^{234} \mathrm{Th}$ on rarer large particles), we find that all data sets subsequent to the equatorial Pacific show evidence for increasing or constant $\mathrm{C} /{ }^{234} \mathrm{Th}$ versus increasing size. Examples can be found in the Arabian Sea (Buesseler et al., 1998), equatorial Atlantic (Charette and Moran, 1999), Ross Sea (Cochran et al.,
2000), Southern Ocean (Buesseler et al., 2001), oligotrophic Pacific (Benitez-Nelson et al., 2001), Labrador Sea (Moran et al., 2003), and elsewhere (Table 1). An exception to this pattern are recent studies of the Gulf of Mexico, where a single large volume in situ pumping system was used, but separate samples for POC and ${ }^{234} \mathrm{Th}$ were collected using separate filtration rigs (membrane filters for $\mathrm{C}$ and cartridges for ${ }^{234} \mathrm{Th}$; Guo et al., 2002a; Hung et al., 2004). Using a single filter does not assure unbiased sampling, however the $\mathrm{C} /{ }^{234} \mathrm{Th}$ ratio measured on a single filter is at least representative of the material that is caught under one set of conditions as opposed to comparing separate samples collected with differing conditions.

Unpublished data from a CLIVAR cruise along $140^{\circ} \mathrm{E}$ in the Southern Ocean, have resulted in more detailed size fractionation measurements of $\mathrm{C} /{ }^{234} \mathrm{Th}$ for as many as five particle size classes between 1 and $>210 \mu \mathrm{m}$, all collected with a single large volume pumping system (Fig. 3). While the absolute $\mathrm{C} /{ }^{234} \mathrm{Th}$ ratio varies somewhat between stations, there is a general trend of increasing or unchanging $\mathrm{C} /{ }^{234} \mathrm{Th}$ ratio with size at any given station. 


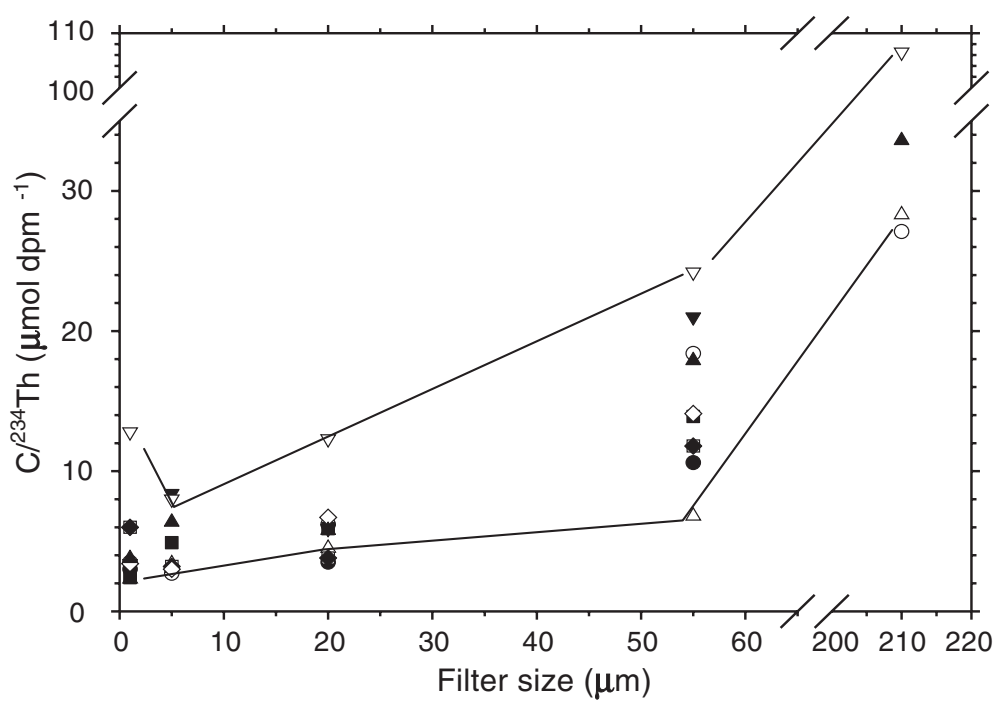

Fig. 3. C $/{ }^{234} \mathrm{Th}$ vs. filter pore size. Samples collected from $100 \mathrm{~m}$ on a transect from Sub-Antarctic to Seasonal Ice Zone (Australian sector) during austral spring of 2001. Samples are pumped sequentially through $210,53,20$, and $5 \mu \mathrm{m}$ screens and $1 \mu \mathrm{m}$ quartz filter, and the same material from each filter is analyzed for ${ }^{234} \mathrm{Th}$ followed by POC. Different symbols represent different stations, and the upper and lower lines connect samples from the same station with highest and lowest $\mathrm{C} /{ }^{234} \mathrm{Th}$ trends, respectively. Pumping system described in Trull and Armand (2001). Experimental setting and total ${ }^{234} \mathrm{Th}$ profiles and fluxes reported in Savoye et al. (2004). Unpublished POC and particulate ${ }^{234}$ Th data from Savoye, Buesseler, and Trull.

When one looks at the many studies of $\mathrm{C} /{ }^{234} \mathrm{Th}$ versus size that employ single sampling methods and filters, it now appears that $\mathrm{C} /{ }^{234} \mathrm{Th}$ increases with or is roughly constant for particles $>1 \mu \mathrm{m}$, the exception being the two early studies in the equatorial Pacific and the Gulf of Mexico (Table 1). Thus $V:$ SA and particle aggregation may explain most particulate $\mathrm{C} /{ }^{234} \mathrm{Th}$ changes with size. Nonetheless, other processes certainly play a role. Since sinking velocity is not just a function of particle size, but also of density difference between the particle and surrounding media, it is difficult a priori to attribute all of the ${ }^{234} \mathrm{Th}$ and $\mathrm{C}$ flux to the largest size class. However, most models predict sinking velocities to increase with size. As a result, many groups have used $\mathrm{C} /{ }^{234} \mathrm{Th}$ from the larger size classes, typically $53 \mu \mathrm{m}$ or larger, whenever possible to represent their best estimate of the $\mathrm{C} /{ }^{234} \mathrm{Th}$ ratio on sinking particles. With size fractionated data, $\mathrm{C} /{ }^{234} \mathrm{Th}$ of the smaller size classes can, with this model, be used as a lower limit on the overall flux prediction (assuming $\mathrm{C} /{ }^{234} \mathrm{Th}$ is lower on small particles, see for example, Buesseler et al., 1998). Sinking velocities, particle concentrations, and $\mathrm{C} /{ }^{234} \mathrm{Th}$ in each size class would be needed to obtain a flux weighted $\mathrm{C} / \mathrm{Th}$ for the ideal application of this approach. This type of sampling based upon settling velocity and flux is beginning to be tested (see new particle sampling technologies).

\section{4. $C /{ }^{234}$ Th vs. depth relationships}

The ${ }^{234} \mathrm{Th}$ flux approach for determining $\mathrm{C}$ export is based upon the premise that one knows the $\mathrm{C} / \mathrm{Th}$ ratio of sinking particles at the depth where one is calculating POC flux. This is especially important, since in most data sets, $\mathrm{C} /{ }^{234} \mathrm{Th}$ decreases with depth (Fig. $4 \mathrm{a}-\mathrm{c}$ ) and the use of a shallower $\mathrm{C} /{ }^{234} \mathrm{Th}$ would overestimate POC flux in this case. Size fractionated data show similar trends with depth for different size classes (Buesseler et al., 1998, 2005). There are few sediment trap data sets with $\mathrm{C} /{ }^{234} \mathrm{Th}$ vs. depth information, but thus far these suggest a decrease with depth as well (Buesseler et al., 1992; Fig. 4c). Processes discussed above, such as preferential remineralization of $\mathrm{C}$, changes in surface binding ligands with depth, or simply increasing ${ }^{234} \mathrm{Th}$ activities at depth (and thus higher particulate ${ }^{234} \mathrm{Th}$ partitioning) are commonly invoked to explain higher particulate ${ }^{234} \mathrm{Th}$ and thus lower C ${ }^{234}$ Th at depth (Rutgers van der Loeff et al., 2002).

In many studies, $\mathrm{C} /{ }^{234} \mathrm{Th}$ variability is much greater in surface waters than at depth, suggesting a large role for biological processes in setting $\mathrm{C} /{ }^{234} \mathrm{Th}$, since the variability in these processes decrease below the euphotic zone. Thus using $\mathrm{C} /{ }^{234} \mathrm{Th}$ below the mixed layer more tightly constrains the predicted $\mathrm{C}$ flux. For example, surface water $\mathrm{C} /{ }^{234} \mathrm{Th}$ in the Arabian Sea has a relative standard deviation about the mean that is 2.5 

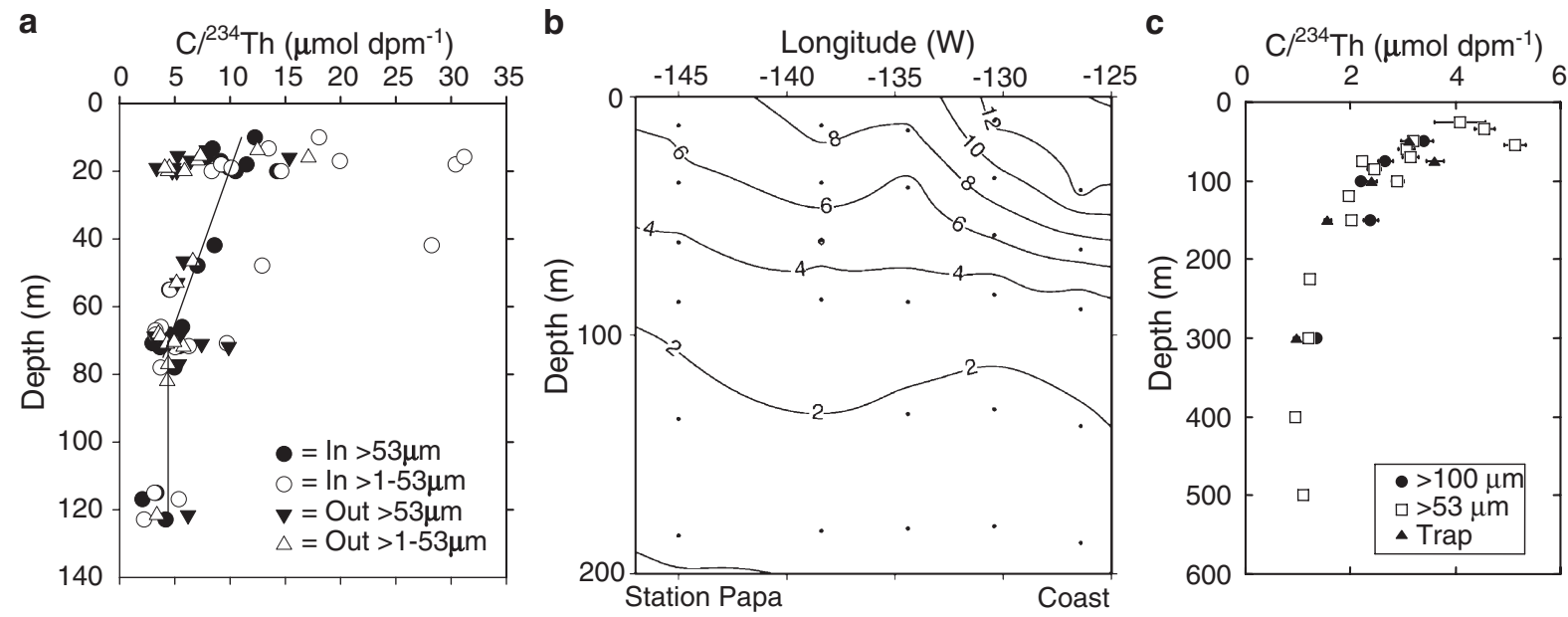

Fig. 4. a-c. Selected examples of $\mathrm{C} /{ }^{234} \mathrm{Th}$ vs. depth. (a) $\mathrm{C} /{ }^{234} \mathrm{Th}$ in particles $>1-53$ and $>53 \mu \mathrm{m}$ collected using in situ pumps as part of US Southern Ocean Iron Experiment for stations within (In) and outside (Out) of the Fe fertilized patch (Buesseler et al., 2005). Solid line is linear fit to $\mathrm{C} /{ }^{234} \mathrm{Th}$ between $10-75 \mathrm{~m}$ and average of $\mathrm{C} /{ }^{234} \mathrm{Th}$ below $80 \mathrm{~m}$ for "In" station $>53 \mu \mathrm{m}$ samples. (b) $\mathrm{C} /{ }^{234} \mathrm{Th}$ collected using in situ pumps and a $1 \mu \mathrm{m}$ filter on a transect of 5 stations between coastal NE Pacific and off shore time series station "Papa" (Charette et al., 1999). (c) C/ ${ }^{234} \mathrm{Th}$ ratios collecting in the south Aegean Sea, March 2004, using free-floating, surface-tethered sediment traps and large-volume in situ pump with 100 and $53 \mu \mathrm{m}$ Nitex screens (Moran, unpublished data). Error bars are derived from ${ }^{234} \mathrm{Th}$ analyses and are shown if larger than the symbol.

times larger than at $100 \mathrm{~m}$ (calculated from data in Buesseler et al., 1998). The same was seen in the Southern Ocean (Fig. 4a). Charette et al. (1999) found a larger range in $\mathrm{C} /{ }^{234} \mathrm{Th}$ in surface waters along a transect from the coast to off shore waters, relative to $\mathrm{C} /{ }^{234} \mathrm{Th}$ below $50-100 \mathrm{~m}$ (Fig. 4b). The possibility of lower $\mathrm{C} /{ }^{234} \mathrm{Th}$ variability at depth is an advantage in using $\mathrm{C} /{ }^{234} \mathrm{Th}$ on particles collected from below the surface mixed layer. This of course depends on the fidelity of obtaining an estimate of the sinking $\mathrm{C} /{ }^{234} \mathrm{Th}$ ratio from concentration data using filters. It is possible that the advantages of low variability in $\mathrm{C} /{ }^{234} \mathrm{Th}$ at depth are offset by methodological biases if there are classes of rapidly sinking particles that are not sampled using filters.

Due to sampling limitations, some studies have either taken a shallow water ratio of $\mathrm{C} /{ }^{234} \mathrm{Th}$ and applied a correction factor based upon measurements of the decrease in $\mathrm{C} /{ }^{234} \mathrm{Th}$ observed at a few representative stations (Buesseler et al., 1995), or assumed that the $\mathrm{C} /{ }^{234} \mathrm{Th}$ variation between surface and depth is small. If only surface water $\mathrm{C} /{ }^{234} \mathrm{Th}$ data are available, it is difficult to constrain export of $\mathrm{C}$ at depth better than a factor of $2-10$, i.e., the difference in $\mathrm{C} /{ }^{234} \mathrm{Th}$ observed between surface and deeper waters. At a minimum, one should have $\mathrm{C} /{ }^{234} \mathrm{Th}$ data from one depth below the mixed layer and a well characterized total ${ }^{234} \mathrm{Th}:{ }^{238} \mathrm{U}$ activity ratio in the water above, in order to calculate a $\mathrm{C}$ flux at that specific depth. Highly resolved vertical sampling of $\mathrm{C} /{ }^{234} \mathrm{Th}$ is not required to determine a flux at a single depth, but depth varying patterns of both ${ }^{234} \mathrm{Th}:{ }^{238} \mathrm{U}$ and $\mathrm{C} /{ }^{234} \mathrm{Th}$ allow for study of $\mathrm{C}$ flux vs. depth dynamics that may lend insight into particulate $\mathrm{C}$ and ${ }^{234}$ Th flux relationships (Bacon et al., 1996; Buesseler et al., 2005).

\section{Regional variations in $\mathrm{C} /{ }^{234} \mathrm{Th}$}

Early data suggest lower $\mathrm{C} /{ }^{234} \mathrm{Th}$ in the equatorial Pacific, relative to diatom bloom conditions and high latitude sites (Buesseler, 1998). These regional differences are most apparent if we compare data collected by a single method, and we focus here on a regional comparison of $\mathrm{C} /{ }^{234} \mathrm{Th}$ from samples collected below the mixed layer (Fig. 5). For example, using measurements from sediment traps (typically drifting traps in the upper $100-300 \mathrm{~m}$ ), C/ ${ }^{234} \mathrm{Th}$ is $<5$ in the oligotrophic settings of HOT, BATS, EqPac and the Mediterranean, with higher values $(>10)$ in biologically productive coastal settings, such as Baffin Bay and Arabian Sea coastal waters (Fig. 5a). Particles sampled via in situ pumps (typically $\geq 53$ or $70 \mu \mathrm{m}$ ) also show a similar trend (based upon many more samples but fewer locations) with $\mathrm{C} /{ }^{234} \mathrm{Th}>10$ for the Ross Sea and Baffin Bay, both high latitude sites and productive coastal systems (Fig. 5b). C/ $/^{234} \mathrm{Th}$ derived from small volume bottle filtrations (generally 0.5 to $1.0 \mu \mathrm{m}$ pore size filters) are consistently higher than both large volume pumps and sediment traps at the same sites, with no $\mathrm{C} /{ }^{234} \mathrm{Th}<5$, and most $>10$ (Fig. $5 \mathrm{c}$ ). In these 

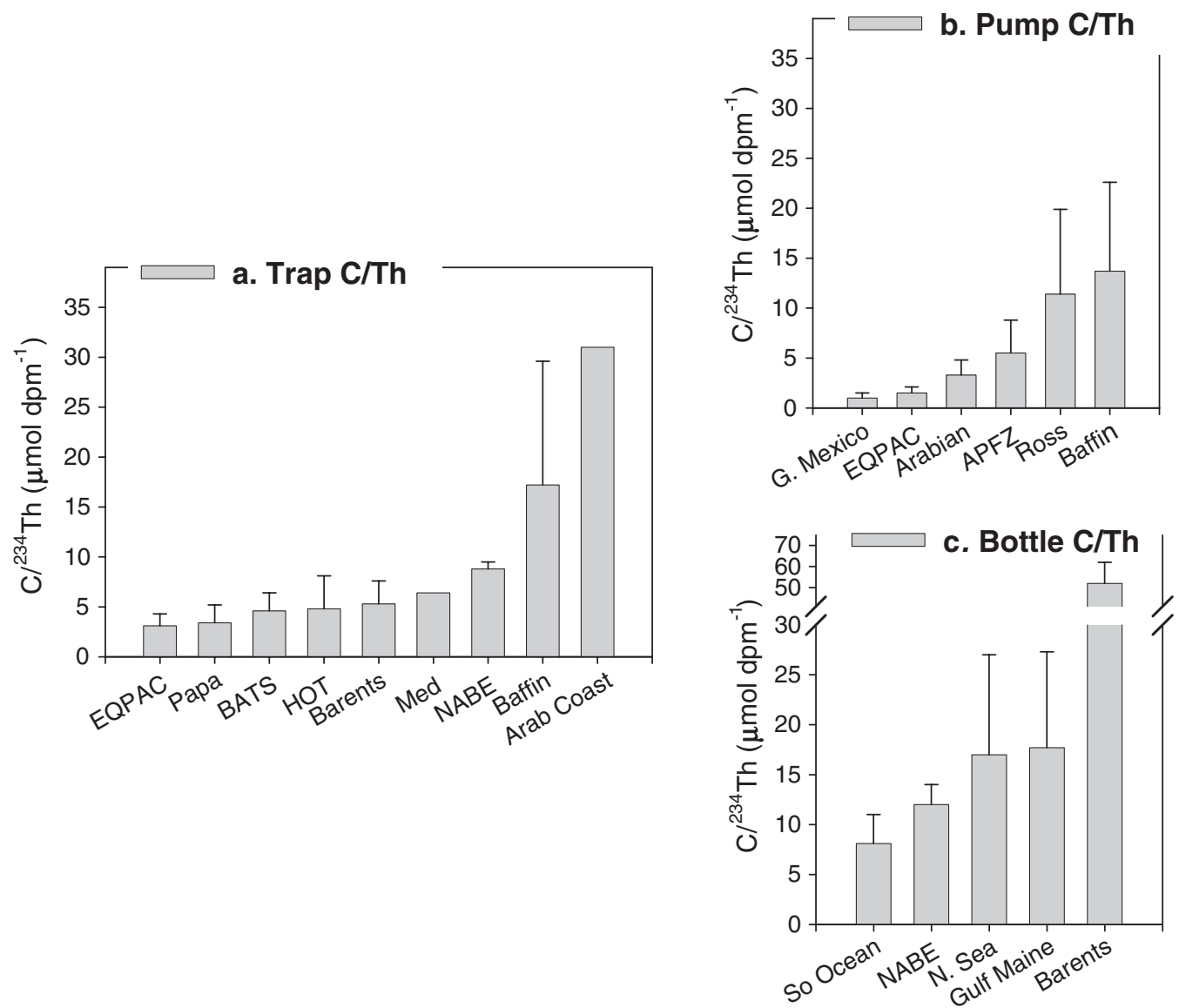

Fig. 5. a-c. Regional variations in $\mathrm{C} /{ }^{234} \mathrm{Th}$, grouped by the three common sampling methods and reported as the mean and standard deviation (shown as error bar) for samples collected below the mixed layer, generally 100-150 m. For sediment trap (a), references include: EqPacBuesseler et al. (1995); Papa — Charette et al. (1999); BATS — Buesseler et al., unpub. 1993-1995 data; HOT—Benitez-Nelson et al. (2001); Barents Sea-Coppola et al. (2002); Mediterranean-Schmidt et al. (2002); NABE-North Atlantic Bloom Experiment—Buesseler et al. (1992); Baffin Bay-Amiel et al. (2002); Arabian Coastal-Buesseler et al. (1995), subset of original data from coastal sites. In situ pump samples in (b) are typically $>53$ or $70 \mu \mathrm{m}$ particles; references include: same as (a), plus Gulf of Mexico-Hung et al. (2004); APFZ—Antarctic Polar Frontal ZoneBuesseler et al. (2001); Ross Sea-Cochran et al. (2000). For bottle samples in (c) typically $>0.1$ or $1.0 \mu$ m; references include same as (a) and (b), plus, Southern Ocean—Buesseler et al. (2001), North Sea—Gustafsson et al. (2000b); Gulf of Maine—Benitez-Nelson et al. (2000).

bottle samples, the ratio and variability is especially high in coastal settings. From these trends, we conclude that productive coastal waters and high latitudes are characterized by particles that have elevated and variable $\mathrm{C} /{ }^{234} \mathrm{Th}$. One hypothesis for this difference that fits the $V$ :SA model is that sites dominated by sinking of large cells (high latitudes and coastal blooms) have elevated $\mathrm{C} /{ }^{234} \mathrm{Th}$. Those dominated by small particles and typically lower relative particle fluxes (oligotrophic settings) have lower $\mathrm{C} /{ }^{234} \mathrm{Th}$.

While $\mathrm{C} /{ }^{234} \mathrm{Th}$ might increase with a shift from picoplankton to communities with larger phytoplankton, in particular diatoms, one should also consider zooplankton processing. In waters with relatively large zooplankton populations, the flux of fecal pellets would contribute more significantly to POC flux. C assimilation rates for ingestion and preferential loss of $\mathrm{C}$ from fecal pellets, result in lower $\mathrm{C} /{ }^{234} \mathrm{Th}$ in larger pellets (Fisher et al., 1987; Reinfelder and Fisher, 1991; Lee and Fisher, 1992). Thus a shift from a region where flux is dominated by phytodetritus to one with higher zooplankton grazing and $\mathrm{C}$ export as fecal pellet material would result in a shift to lower $\mathrm{C} /{ }^{234} \mathrm{Th}$ ratios. In essence, both phytoplankton community structure and zooplankton grazing need to be considered in order to understand regional variability in $\mathrm{C} /{ }^{234} \mathrm{Th}$. It should be possible to use site specific plankton abundance data and models that incorporate assimilation and regenera- 
tion of $\mathrm{C}$ and ${ }^{234} \mathrm{Th}$ to better understand and predict the impact of changing food web processes on regional $\mathrm{C} /{ }^{234} \mathrm{Th}$ relationships. Since regional variations have been shown to be large (Fig. 5), site specific data are needed in any case.

\section{Temporal changes in $\mathrm{C} /{ }^{234} \mathrm{Th}$}

Temporal changes in upper ocean biology, particle sources, and particle geochemistry should be expected to impact $\mathrm{C} /{ }^{234} \mathrm{Th}$. This is because the processes that set the $\mathrm{C} /{ }^{234} \mathrm{Th}$ ratio can vary within a given particle size class as a result of seasonal variations in the biological community at any one site. This would be particularly significant in the euphotic zone, where primary biological particles are formed and packaged into sinking ones. Waite and Hill (2006-this volume) modeled the progression of a diatom bloom wherein diatom cells sank both as single cells and as aggregates that dominate the export flux late in a bloom cycle. They predict that the $\mathrm{C} /{ }^{234} \mathrm{Th}$ ratio of the truly sinking material could decrease over time as these smaller particles are incorporated in the flocs. If this were the case, one would need to account for this shift to flocs with lower $\mathrm{C} /{ }^{234} \mathrm{Th}$, rather than rely on the assumption that the largest particles always dominate export.

$\mathrm{C} /{ }^{234} \mathrm{Th}$ is influenced by changes in particle sources, sinking velocities (and these may not always follow size), solution chemistry, and remineralization of $\mathrm{C}$ and ${ }^{234} \mathrm{Th}$ associated with sinking particles. As such, both regional and time-specific $\mathrm{C} /{ }^{234} \mathrm{Th}$ ratios are the key to the proper application of the empirical approach. One example of seasonal variability in $\mathrm{C} /{ }^{234} \mathrm{Th}$ comes from the Baltic where changing particle sources throughout the year and changing water column biogeochemistry are postulated to be responsible for the factor of 10 seasonal variability in $\mathrm{C} /{ }^{234} \mathrm{Th}$ on filterable particles collected from the mixed layer (Fig. 6; Gustafsson et al., 2004). Not all studies, however, show such a dynamic shift in $\mathrm{C} /{ }^{234} \mathrm{Th}$ during a seasonal cycle. For example, at the open ocean time series site off Hawaii (HOT), there is only a factor of 2-3 variability at $150 \mathrm{~m}$ in this ratio, based upon measurements made over an annual cycle using size fractionated filtration (particles ranging in size from 1 to $\geq 53 \mu \mathrm{m}$ size classes) and sediment traps (Table 2 in BenitezNelson et al., 2001). Collectively, these studies suggest that seasonal variability in $\mathrm{C} /{ }^{234} \mathrm{Th}$ may be impacted by a wide range of processes that are both regional and depth-related. It would be inappropriate to apply a single $\mathrm{C} /{ }^{234} \mathrm{Th}$ estimate made at one location to the same site under differing conditions, just as it is inap-

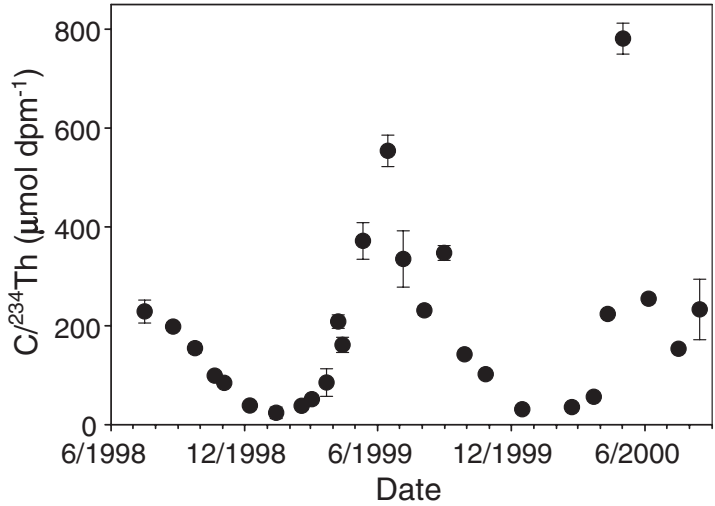

Fig. 6. $\mathrm{C} /{ }^{234} \mathrm{Th}$ ratios in Baltic Sea mixed layer collected using a surface pumping system on $1 \mu \mathrm{m}$ filters (Gustafsson et al., unpublished data). Error bars represent propagated uncertainties (1 s.d.) derived from both POC and ${ }^{234} \mathrm{Th}$ analyses, and are shown if larger than the symbol.

propriate to use shallow $\mathrm{C} /{ }^{234} \mathrm{Th}$ to estimate deeper fluxes.

\section{Methodological issues-traditional particle sampling methods}

We have shown that regional and size variations in $\mathrm{C} /{ }^{234} \mathrm{Th}$ are most apparent when $\mathrm{C} /{ }^{234} \mathrm{Th}$ data are compared using a single sampling device, since differences between collection techniques have been documented (e.g., Buesseler et al., 1995; Murray et al., 1996). Which sampling system best represents truly sinking material is a more difficult question to answer. Nevertheless, it is useful to summarize data comparing different particle sampling devices with comments regarding possible sampling biases, so that variability between samples may be evaluated in terms of biology and geochemistry.

Fundamentally, one would presume that sinking particles would be best represented by that material caught in a sediment trap. However, there are inherent difficulties in using upper ocean sediment traps that might impact not just the quantity of flux (Buesseler, 1991), but also the quality (Gustafsson et al., 2004; Stanley et al., 2004). There are three common processes that may impact trap results (for complete review, see Gardner, 2000): collection efficiency related to how the trap samples sinking particles while moving in a fluid medium (hydrodynamic effects); the capture of nonsinking and motile zooplankton (i.e., swimmers); and the loss of particulate bound elements to solution after collection in the trap and during sample handling or storage (resolubilization). Each of these processes would likely result in not just a total flux bias, but 
also elemental fractionation. For instance, hydrodynamics might preferentially impact particles of different settling velocities (e.g., under/over collection related to sinking velocity; Gust et al., 1996). Chemical composition changes might lead to differential resolubilization rates after collection, including loss of $\mathrm{C}$ to solution (Gardner et al., 1983; Noji et al., 1999; Antia, 2005). Variations in $\mathrm{C} /{ }^{234} \mathrm{Th}$ might be attributed to the number of swimmers that are collected in a trap, since this ratio can be highly elevated in zooplankton (Coale, 1990; Passow et al., 2006-this volume). Significant progress is being made in new trap designs that avoid or at least reduce some of these potential issues (see new particle sampling technologies).

Particle filtration is the most commonly used method to sample particles for $\mathrm{C} /{ }^{234} \mathrm{Th}$. In earlier experiments, bottle POC data were compared to ${ }^{234} \mathrm{Th}$-derived from individual cartridge filters or other particle collectors, such as in Buesseler et al. (1992). With increased awareness of the differences in each collection device and the importance of representative $\mathrm{C} /{ }^{234} \mathrm{Th}$ ratios for application of the Th method, there was a subsequent use of large volume in situ pumps that allowed for measurement of $\mathrm{C}$ and ${ }^{234} \mathrm{Th}$ on the same filter. Also, larger volumes permitted size fractionation work, and, thus characterization of $\mathrm{C} /{ }^{234} \mathrm{Th}$ on the larger, rarer and presumably more rapidly sinking materials.

$\mathrm{C} /{ }^{234} \mathrm{Th}$ ratios of particles collected from bottles (typically 2-5 L samples) are more often higher than ratios collected by either pumps or traps from the same regional setting and depths (Fig. 5). This is most likely due to an elevation in bottle POC as has been confirmed by a range of studies that directly compare bottles and pumps using small pore sized filters $(0.7-1 \mu \mathrm{m}$ diameter) typically made of glass or quartz fiber (Moran et al., 1999; Gardner et al., 2003; Liu et al., 2005). At low POC concentrations (few $\mu \mathrm{M}$ POC) this bias has been attributed to dissolved organic carbon (DOC) sorption on to the filter. This bias would be higher in high DOC surface waters and more evident in small volume bottle samples (Moran et al., 1999). One alternative explanation is simply that bottle POC is higher due to the smaller pore size of GFF filters (nominal pore size of $0.7 \mu \mathrm{m}$ ) used with bottle POC methods vs. the quartz filters (nominal pore size of $1 \mu \mathrm{m}$ ) typically used with pumps (Dunne et al., 1997; Gardner et al., 2003). For example, Dunne et al. (1997) compared collection of chlorophyll and ${ }^{234} \mathrm{Th}$ from bottle and pump pairs and concluded that pump POC concentrations had to be increased by a factor of 1.1 to 2.3 for accurate comparison with bottle POC because of the pore size differences and the abundance of small cells in their study.
Conversely, it has been suggested that the higher crossfilter pressure differentials created with in situ pumps causes particle break-up and thus reduced retention of fragile/flexible high C particles (e.g., TEP and bacteria), leading to a bias of low POC with pumps (Gardner et al., 2003).

Given that POC represents a spectrum of particle sizes, types and sources, these variations are likely site, season and depth specific. For example, in sub-zero temperature waters, this difference between bottle and pump POC is most pronounced (Gardner et al., 2003), but the reason for this larger difference is not yet explained. The most recent study on this issue by Liu et al. (2005) systematically varied pumping and bottle filtration conditions at different sites, and corrected for possible DOC adsorption blanks. They observed no difference in bottle vs. pump chlorophyll concentrations, but found enhancement of POC in nearly half of the bottle POC samples. Their conclusion is that marine sample bottles preferentially capture motile zooplankton relative to most current pumping systems. This leads to enhanced POC on some bottle filter samples derived from living zooplankton, rather than from truly sinking material. This bias is similar to collecting zooplankton or "swimmers" in shallow traps, which artificially bias trap $\mathrm{C} /{ }^{234} \mathrm{Th}$ ratios towards higher values.

Whatever its ultimate cause, observations suggest that methodological differences need to be addressed if we wish to use filtration to assess $\mathrm{C} /{ }^{234} \mathrm{Th}$ variability, and hence apply the ${ }^{234} \mathrm{Th}$ flux approach in the ocean more precisely. In the meantime, if it can be shown for a given setting that sediment traps and large volume filtration methods are comparable, then these different collection techniques may be used to constrain minimum and maximum estimates of particle export. From regional analyses and site specific studies where both traps and filtration have been used, sediment trap $\mathrm{C} /{ }^{234} \mathrm{Th}$ are generally within a factor of two of $\mathrm{C} /{ }^{234} \mathrm{Th}$ of large particles collected using in situ pumps (Benitez-Nelson et al., 2001; Fig. 4c). This convergence of trap and large particle data from pumps is encouraging, but not the final story on how best to sample truly sinking particles for $\mathrm{C} /{ }^{234} \mathrm{Th}$ (see new particle sampling technologies).

It should be noted at this point, that if we had the ideal particle flux collector, we could rely on direct collection of sinking particles, but as discussed, standard shallow sediment traps have possible biases in flux and composition. However, even if these issues can be overcome, shallow sediment traps are typically deployed for days to weeks at fixed or single moving 
points, limiting spatial and temporal coverage. It is therefore still desirable to have a more efficient and cost-effective way to estimate particle export over large geographical areas. With the ${ }^{234} \mathrm{Th}$ approach, one can collect hundreds of water samples on a single cruise. Thus, it may be better to use sediment traps (or pumps) to determine $\mathrm{C} /{ }^{234} \mathrm{Th}$ at a few points in space and time, and use total ${ }^{234} \mathrm{Th}:{ }^{238} \mathrm{U}$ to obtain a more detailed coverage of particle flux variability. Thus far, $\mathrm{C} /{ }^{234} \mathrm{Th}$ variability at depths below the mixed layer has been smaller than changes in ${ }^{234} \mathrm{Th}$ fluxes above (for example at HOT-Benitez-Nelson et al., 2001) and during iron fertilization experiments (Buesseler et al., 2005), but this would need to be considered in designing any flux study.

\section{Methodological issues-new particle sampling technologies}

\subsection{Neutrally buoyant sediment traps}

Since hydrodynamic effects caused by fluid flow, tilt, and vertical motion in sediment traps may lead to particle sampling biases, development of sediment traps that reduce trap motion relative to the surrounding fluids is encouraged. Recently, neutrally buoyant sediment traps (NBSTs), have been developed which by design, decrease the hydrodynamic effect, since the velocity relative to surrounding water of a neutrally buoyant float is near zero (Valdes and Price, 2000; Buesseler et al., 2000; Lampitt et al., 2004; Stanley et al., 2004). In the first set of deployments off Bermuda the flux and composition of NBSTs and standard drifting particle interceptor traps (PITS) were compared. PITS are tethered to a surface float and are known to have significant flow over and within the trap collection tubes (Gardner, 2000). Under relatively benign and low flux conditions (mean current velocities relative to PITS traps of 4-5 $\mathrm{cm} \mathrm{s}^{-1}$ and excursions $<10 \mathrm{~cm} \mathrm{~s}^{-1}$ ), there was good agreement between NBSTs and PITS in total mass and $\mathrm{C}$ flux but differences in minor flux components (Buesseler et al., 2000). For C/ ${ }^{234} \mathrm{Th}$, the NBST was 2-3 times higher than the PITS. Since the expected hydrodynamic bias was undercollection of slowly sinking particles in the PITS, the explanation for this bias may be that NBSTs collected a higher fraction of a slowly sinking, elevated $\mathrm{C} /{ }^{234} \mathrm{Th}$ material.

Subsequent NBST studies at the same site have confirmed that while differences in bulk parameters may be small, minor flux components may differ significantly in the NBST. This is presumably due to fractionation or different collection efficiencies for different particle types (Stanley et al., 2004). Fig. 7 shows a comparison of the relative $\mathrm{C} /{ }^{234} \mathrm{Th}$ ratio in material caught by NBSTs and PITS as well as in size fractionated, $>1-70$ and $\geq 70 \mu \mathrm{m}$, particles collected using in situ pumps (all data from $150 \mathrm{~m}$ collected during 4 cruises). The trap data are from three day deployments and average concentrations are derived from at least two separate trap collection tubes. The pump data are from a single collection at $150 \mathrm{~m}$. As with the earlier study, NBST $\mathrm{C} /{ }^{234} \mathrm{Th}$ are, on average, almost twice as high as the ratio measured in PITS. What is perhaps surprising is that the $\mathrm{C} /{ }^{234} \mathrm{Th}$ of the NBST is higher than both the small and large particles collected using pumps. This implies that there is a $\mathrm{C}$ rich source of sinking material that is undercollected by the more common sampling methods, i.e., filtration and PITS. We should note that there were compromising analytical issues in this particular data set, as $\mathrm{C}$ was not

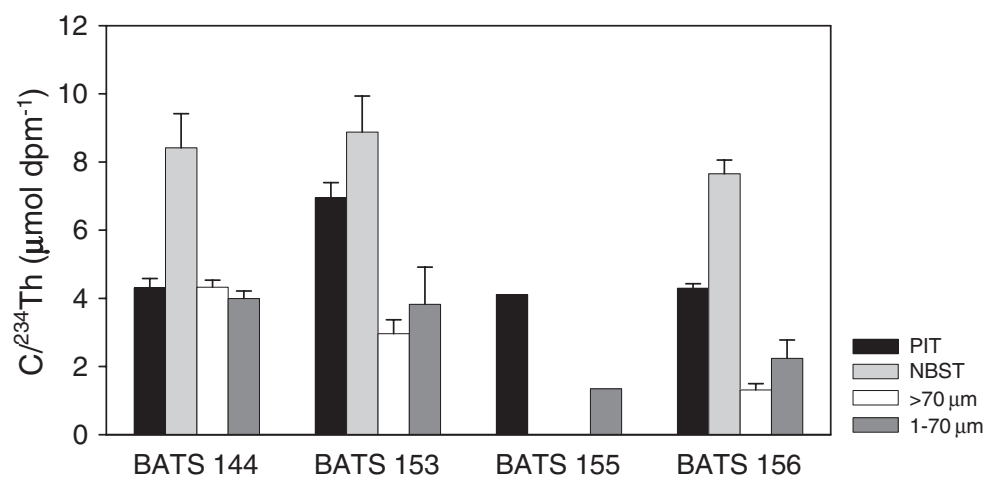

Fig. 7. $\mathrm{C} /{ }^{234} \mathrm{Th}$ for NBST, PIT and $>1-70$ and $>70 \mu \mathrm{m}$ particles collected via in situ pumps at $150 \mathrm{~m}$ at the Bermuda Atlantic Time-Series (BATS) station (Buesseler et al., unpublished data). Four sets of comparisons are shown from different BATS cruises. Error bars on PIT and NBST are derived from variability between sampling tubes which were analyzed separately for POC (generally 3-4 tubes) or 234Th (generally 2 tubes). Error bars on in situ pump data are from combined POC and ${ }^{234} \mathrm{Th}$ analytical uncertainty of a single sample. 
analyzed from the same collection tube as ${ }^{234} \mathrm{Th}$. Stanley et al. (2004) noted large tube to tube differences in flux for both NBSTs and PITS at this site. Also, the pump filters were collected only once during a 3 day trap collection period and processed separately by different labs and methods for POC on the traps and filters. Nonetheless this enrichment in $\mathrm{C} /{ }^{234} \mathrm{Th}$ in NBST is confirmed by another new ocean particle collection device, SPLITT (split flow thin cell fractionation; Gustafsson et al., 2006-this volume) may also better sample this slowly sinking pool (see Split flow thin cell fractionation below).

\subsection{Settling velocity traps}

During the MedFlux program, an Indented Rotating Sphere (IRS) sediment trap (Peterson et al., 1993) was deployed at the Mediterranean DYFAMED site (Marty, 2002). The trap was operated in a fashion such that it could separately collect particles settling at different velocities. The sphere was allowed to collect particles for $24 \mathrm{~h}$, at which point it rotated and released the particles to the lower portion of the trap. The carousel containing the collection cups rotated completely once per day, timed to begin with the rotation of the sphere. Each cup was kept open for different, progressively longer lengths of time, allowing particles with different settling speeds to collect in different cups. Slowly settling material collected in the later cups. The cups corresponding to the settling velocities integrated settling particles over the length of the deployment. Mass fluxes were calculated as the total amount of material accumulated in each cup over the length of the deployment. Splits from each cup were analyzed for ${ }^{234} \mathrm{Th}$ (by nondestructive low level beta counting) and POC. Details of this experiment and other results were presented by Cochran et al. (2004).

Two IRS traps were deployed for 61 days in the settling velocity mode at $200 \mathrm{~m}$. The greatest mass and ${ }^{234} \mathrm{Th}$ flux was recorded in the fraction settling at velocities to be between 196 and $490 \mathrm{~m} \mathrm{~d}^{-1}$, with $>60 \%$ of the total ${ }^{234} \mathrm{Th}$ flux in those particles sinking at rates estimated to be $>98 \mathrm{~m} \mathrm{~d}^{-1}$ (data not shown). The POC $/{ }^{234} \mathrm{Th}$ ratio in the trapped material is shown relative to the minimum settling velocity for each fraction in Fig. 8. There is relatively little variation among the settling velocity classes. Indeed if a trend is present, it is a tendency for the ratio to increase as settling velocity decreases. This is not consistent with the expectation of small, slowly settling particles having high surface area and hence high ${ }^{234} \mathrm{Th}$ activity. Additional analyses of the organic compounds and biomarkers of the different fractions are underway to resolve the differences. During this experiment, $\mathrm{C} /{ }^{234} \mathrm{Th}$ was also determined using in situ pumps at $200 \mathrm{~m}$, and the $\mathrm{C} /{ }^{234} \mathrm{Th}$ ratio of these filtered samples were similar to the flux weighted averages of the settling velocity trap (2.4 and 3.2 on $1-70 \mu \mathrm{m}$ and $\geq 70 \mu \mathrm{m}$ size classes, respectively; Cochran et al., 2004) These data are encouraging for the ${ }^{234} \mathrm{Th}$ flux approach since they imply, at least in this setting, that most particles, both sinking and slowly settling that were sampled via traps or

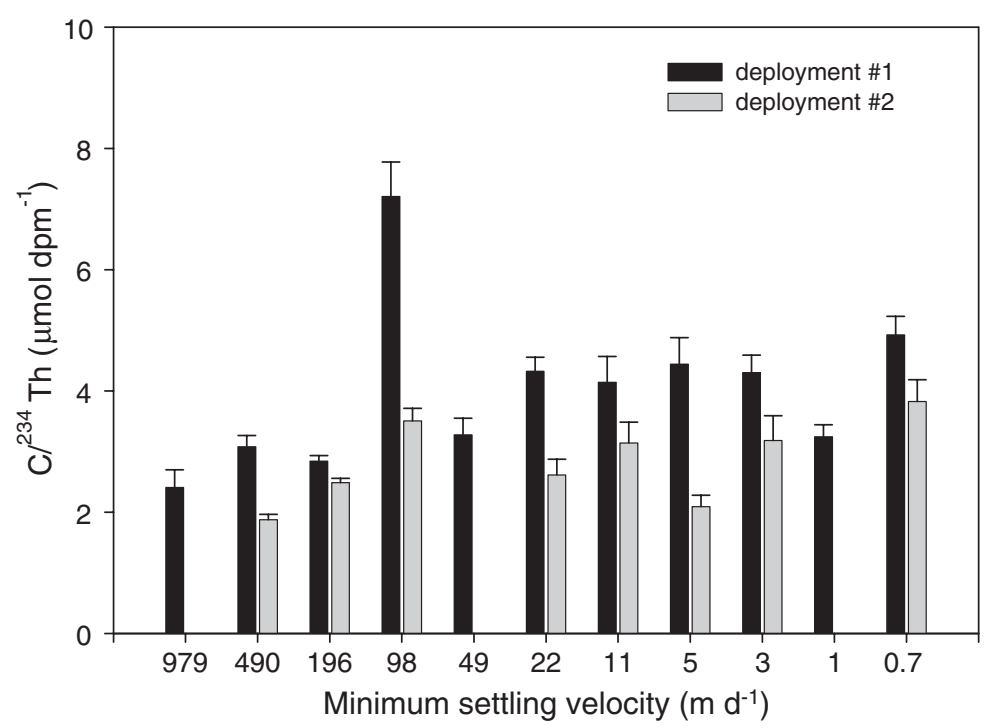

Fig. 8. $\mathrm{C} /{ }^{234} \mathrm{Th}$ for particles separated by settling velocity in the Mediterranean. SV1 and SV2 represent replicate IRS traps deployed at $200 \mathrm{~m}$ for $\sim 2$ months and operated in a settling velocity mode (see text; Cochran et al., 2004). Error bars are derived from error on the ${ }^{234}$ Th analyses. 
filters, all do a reasonable job in representing $\mathrm{C} /{ }^{234} \mathrm{Th}$ on sinking particles.

\subsection{Split flow thin cell fractionation}

SPLITT is a method where particles are introduced into a laminar flow within a thin channel $(100 \mathrm{~s} \mu \mathrm{m})$. The flow is adjusted so that particles greater than a specific sinking velocity are collected at a lower outlet port, while slower sinking particles are channeled out via an upper port (Giddings, 1985). Thus far, SPLITT has been used mostly in biomedical applications and rarely in natural settings due to the low concentration of sinking particles in aquatic systems (Gustafsson et al., 2000b). Much like the settling velocity trap, SPLITT is designed to separate particles based upon hydrodynamic properties, rather than size.

Gustafsson et al. (2006-this volume) describe a high capacity SPLITT system they have optimized for a study of POC and ${ }^{234} \mathrm{Th}$ within the surface mixed layer in coastal waters. In practice, they can adjust the SPLITT to separate particles with sinking velocities less than 1 to $>10 \mathrm{~m} \mathrm{~d}^{-1}$. Due to the low concentrations of rapidly sinking particles in general, they preconcentrate $>100 \mathrm{~L}$ of seawater using a cross flow filtration system $(0.2 \mu \mathrm{m}$ Millipore Pellicon system) prior to SPLITT processing. Gustafsson et al. (2006-this volume) collected SPLITT samples and standard filtered particles via a pumping system that brings water up from a depth near the base of the mixed later, and deployed PITS traps immediately below the mixed layer. Their results from Gullmar fjord show that $\mathrm{C} /{ }^{234} \mathrm{Th}$ in SPLITT samples (adjusted to collect all particles sinking $>1 \mathrm{~m} \mathrm{~d}^{-1}$ ) is significantly higher than the PITS in 4 field deployments (avg. $\mathrm{C} /{ }^{234} \mathrm{Th}$ for SPLITT:PIT $=3: 1$ ), as well as in 3 of 5 comparisons to a $1 \mu \mathrm{m}$ filter (avg. $\mathrm{C} /{ }^{234} \mathrm{Th}$ for SPLITT: filter $=1.5: 1$ ). Gustafsson et al. (2006-this volume) hypothesize that SPLITT does a better job at sampling slowly settling material, which they believe is enriched in $\mathrm{C} /{ }^{234} \mathrm{Th}$. Known hydrodynamic biases are invoked for PITS that would make them less efficient at collecting slowly sinking particles. Truly suspended particles sinking $<1 \mathrm{~m} \mathrm{~d}^{-1}$ are postulated to be TEP and/or APS rich, and thus lower in $\mathrm{C} /{ }^{234} \mathrm{Th}$ ratio due to the higher affinity of ${ }^{234} \mathrm{Th}$ for these surfaces.

These new studies using NBSTs, Settling Velocity Traps and SPLITT to sample sinking particles, do involve more challenging methods than traditional filtration. However, they have great potential if they can be proven to more accurately collect what is truly settling as opposed to material collected based upon its size or impacted by some other sampling bias. Such information would be of great value for the study of $\mathrm{C} /{ }^{234} \mathrm{Th}$ ratios and the general sampling of sinking particles in the ocean. Future studies combining these new methods and measuring $\mathrm{C} /{ }^{234} \mathrm{Th}$ on sinking and size fractionated particles under differing flow and particle conditions are greatly needed.

\section{Comparisons of $\mathrm{C}$ export flux derived from ${ }^{234} \mathrm{Th}$ and other independent methods}

One way to evaluate the accuracy of particulate $\mathrm{C}$ fluxes determined using the ${ }^{234} \mathrm{Th}$ flux approach is by comparison with other methods. Agreement between independent methods, mostly $\mathrm{C}$ and nutrient budgets or incubation rate experiments for $\mathrm{C}$ and $\mathrm{N}$ uptake, lend some confidence to, or at least constrain, upper and lower limits to the overall $\mathrm{C}$ balance. However, it is important to realize that such comparisons are never ideal, since each method has its own assumptions and there are real differences in what is actually measured. In essence, two methods may agree or differ either because they are measuring different components of the local $\mathrm{C}$ pool or are integrating over different space and time scales.

For example, the ${ }^{234} \mathrm{Th}$ activity balance from a single profile represents particle export that has taken place prior to sampling, and integrated over time scales related to the mean life of ${ }^{234} \mathrm{Th}(1 / \lambda=35$ days $)$. Furthermore, it is only measurable when the ${ }^{234} \mathrm{Th}$ flux is large relative to production and decay rates (i.e., the ${ }^{234} \mathrm{Th}:{ }^{238} \mathrm{U}$ method is more sensitive when the deficit is large). Sediment traps are intended to collect passively sinking particles over a fixed period of time that may or may not match the time scale or particle source region sampled by ${ }^{234} \mathrm{Th}$ water column measurements. Measured changes in the concentration or standing stock of $\mathrm{C}$ and other nutrients have been used to derive $\mathrm{C}$ flux by difference, but the difficulty here is related to the large impact of horizontal and vertical exchange; the rates of which are difficult to quantify and the fluxes of which are typically large relative to $\mathrm{C}$ lost via sinking particles. Furthermore, changes in $\mathrm{C}$ stocks are influenced by other processes such as air-sea gas exchange and dissolved organic matter transport. Finally, bottle incubations, i.e., ${ }^{13,14} \mathrm{C}$ or ${ }^{15} \mathrm{~N}$ uptake used to estimate $\mathrm{C}$ and nutrient uptake rates, have their own inherent biases (so-called "bottle effects") and relatively short time scales (hours to 1 day). To make a proper comparison using all of the above techniques, one would need to make repeated measurements over a complete growth and export cycle, since the instantaneous rates of new production and export need not balance, only the longer term average. 
Despite these caveats, it is still instructive to compare $\mathrm{C}$ fluxes based upon the ${ }^{234} \mathrm{Th}$ flux approach to other independent flux indices. The most informative cases are those where multiple methods were used to constrain the $\mathrm{C}$ balance in the upper ocean for an extended observation period. The U.S. Joint Global Ocean Flux Study (JGOFS) Program offers some of the best opportunities for such comparisons, and three examples are shown in Fig. 9a-c. During a 5 week set of observations as part of the North Atlantic Bloom Experiment (Fig. 9a), significant particle export was observed during the onset and development of the spring bloom (Lochte et al., 1993). This first application of the ${ }^{234} \mathrm{Th}$ flux approach (Buesseler et al., 1992) suggested a lower and upper limit of POC flux at $150 \mathrm{~m}$ between $20-70 \mathrm{mmol} \mathrm{C} \mathrm{m} \mathrm{m}^{-2} \mathrm{~d}^{-1}$, depending upon whether one used the $\mathrm{C} / /^{234} \mathrm{Th}$ ratio from suspended small particles (high $\mathrm{C} /{ }^{234} \mathrm{Th}$ ) or trap samples (low $\mathrm{C} /{ }^{234} \mathrm{Th}$ ). Using a mass balance for the drawdown of $\mathrm{CO}_{2}, \mathrm{C}$ losses of $70 \mathrm{mmol} \mathrm{C} \mathrm{m} \mathrm{m}^{-2} \mathrm{~d}^{-1}$ were estimated for the upper $125 \mathrm{~m}$ over the same time period (C. Goyet, personal communication). Nitrate and oxygen budgets for the first two weeks of the bloom in the upper $50 \mathrm{~m}$, suggested a $\mathrm{C}$ loss equivalent to $30-40 \mathrm{mmol} \mathrm{C} \mathrm{m}{ }^{-2} \mathrm{~d}^{-1}$ (Bender et al., 1992). While the ${ }^{234} \mathrm{Th}$-derived flux increased over the course of the bloom, C fluxes measured in VERTEX style cylindrical traps at $150 \mathrm{~m}$ were relatively invariant during three separate two-week deployments, ranging from $7-13 \mathrm{mmol} \mathrm{C} \mathrm{m} \mathrm{m}^{-2} \mathrm{~d}^{-1}$ and were the lowest overall of any method used to estimate $\mathrm{C}$ flux (Martin et al., 1993).

In the Equatorial Pacific Process study (Fig. 9b), three groups made POC flux estimates using the ${ }^{234} \mathrm{Th}$ flux approach but on separate cruises. In all cases, POC fluxes were significantly lower than the earlier North Atlantic Bloom study. Looking at only the boreal spring cruises and equatorial stations along $140^{\circ} \mathrm{W}$, and using either $\geq 53 \mu \mathrm{m} \mathrm{C} /{ }^{234} \mathrm{Th}$ from in situ pumps (Bacon et al., 1996; Buesseler et al., 1995) or
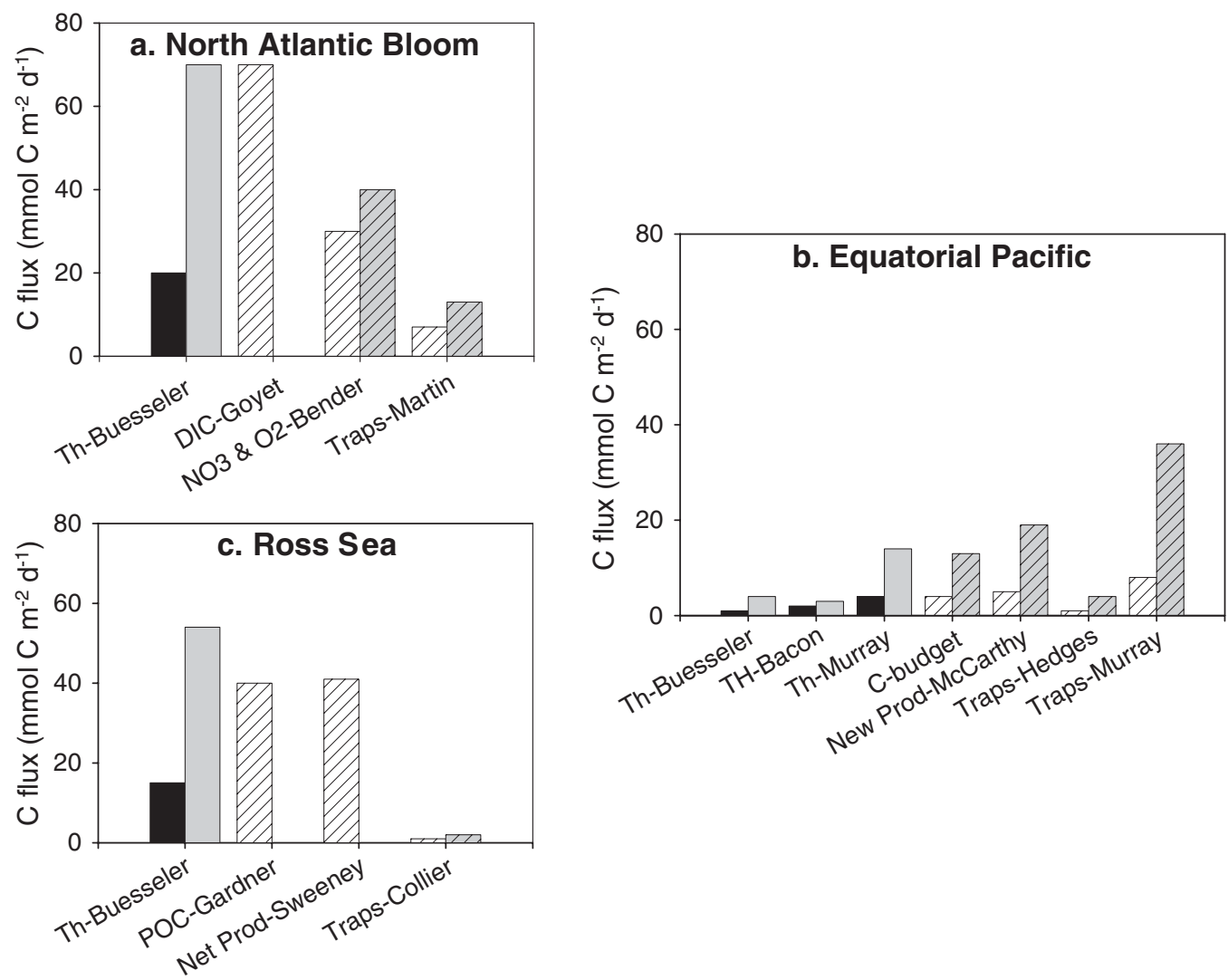

Fig. 9. a-c. A comparison of carbon flux estimates for three US JGOFS Process Studies: (a) North Atlantic Bloom Experiment, (b) Equatorial Pacific (data from $2^{\circ} \mathrm{N}-2^{\circ} \mathrm{S}$ along $140^{\circ} \mathrm{W}$ ), (c) Ross Sea. When two bars are shown for a given method, these represent high and low estimates from the original study (see text for details). All fluxes are plotted on a $Y$ axis scaled to a maximum of $80 \mathrm{mmol} \mathrm{C} \mathrm{m} \mathrm{m}^{-2} \mathrm{~d}^{-1}$ equivalent. See text for references and a discussion of each estimate. 
sediment traps (Murray et al., 1996), POC fluxes were estimated to be $3-6 \mathrm{mmol} \mathrm{C} \mathrm{m}{ }^{-2} \mathrm{~d}^{-1}$ at $100 \mathrm{~m}$ with the higher values calculated when $\mathrm{C} /{ }^{234} \mathrm{Th}$ in trap samples was used. New production determined using ${ }^{15} \mathrm{~N}$ bottle incubations ranged from $<6$ to $19 \mathrm{mmol} \mathrm{C} \mathrm{m} \mathrm{m}^{-2} \mathrm{~d}^{-1}$ (McCarthy et al., 1996). A C budget from DIC and DOC measurements determined a $\mathrm{C}$ flux out of the upper $100 \mathrm{~m}$ of $<5 \mathrm{mmol} \mathrm{C} \mathrm{m}{ }^{-2} \mathrm{~d}^{-1}$ (Feely et al., 1995; Peltzer and Hayward, 1996) and a combined DIC and $\mathrm{DI}^{13} \mathrm{C}$ approach estimated a $\mathrm{C}$ flux between 4 $11 \mathrm{mmol} \mathrm{C} \mathrm{m}^{-2} \mathrm{~d}^{-1}$ (Mang and Quay, 1997). At this same site two sediment trap designs gave POC flux estimates of 1-4 (Wakeham et al., 1997) and 4-36 mmol C $\mathrm{m}^{-2} \mathrm{~d}^{-1}$ at $125 \mathrm{~m}$ (Murray et al., 1996). However, as noted by Murray et al. (1996), the highest fluxes were derived from traps that had significantly overcollected ${ }^{234} \mathrm{Th}$ bearing particles based upon water column ${ }^{234} \mathrm{Th}$ data. Using a more rigorous error and probability analyses, Quay (1997) concluded for the Equatorial Pacific Process study that individual $\mathrm{C}$ flux measurements yielded only a $30 \%$ chance that the DIC budget could be balanced within $\pm 50 \%$ for the surface waters.

One final example from the Ross Sea (Fig. 9c), shows ${ }^{234} \mathrm{Th}$-derived fluxes at $100 \mathrm{~m}$ from three stations ranging from 15 to $54 \mathrm{mmol} \mathrm{C} \mathrm{m}^{-2} \mathrm{~d}^{-1}$ between February and April (Cochran et al., 2000). C fluxes determined by POC balances $(0-100 \mathrm{~m}$; Gardner et al., $2000)$ and net community production (0-200 m; Sweeney et al., 2000) were similar, $\sim 40 \mathrm{mmol} \mathrm{C} \mathrm{m}{ }^{-2} \mathrm{~d}^{-1}$. In contrast, moored conical traps gave a much lower $\mathrm{C}$ flux estimate than any other method $\left(1.5 \mathrm{mmol} \mathrm{C} \mathrm{m}^{-2}\right.$ $\mathrm{d}^{-1}$ ), but these were from deeper depths than those where ${ }^{234} \mathrm{Th}$ was measured $(200 \mathrm{~m}$; Collier et al., 2000). This low trap flux implied either strong remineralization between 100 and $200 \mathrm{~m}$, or undercollection by the traps. A factor of 3-6 undercollection was supported by ${ }^{230} \mathrm{Th}$ and ${ }^{231} \mathrm{~Pa}$ comparisons between traps and the water column budgets conducted as part of this study (Fleisher and Anderson, 2003).

In summary, while there can be differences in the POC flux derived from ${ }^{234} \mathrm{Th}$ at one depth due to the type of materials analyzed for $\mathrm{C} /{ }^{234} \mathrm{Th}$ or the choice of ${ }^{234} \mathrm{Th}$ flux models, POC fluxes derived from the ${ }^{234} \mathrm{Th}$ flux approach overlap with most other estimates of $\mathrm{C}$ export within a factor of two to three. Larger differences between traps and ${ }^{234} \mathrm{Th}$-derived fluxes have been noted previously, and, at least in these three JGOFS process studies, the agreement is best between the ${ }^{234} \mathrm{Th}$-derived $\mathrm{C}$ flux estimates and other non-trap approaches. These ${ }^{234} \mathrm{Th}$ results indicate higher POC export in response to spring bloom conditions in the North Atlantic and after retreat of sea ice in the Ross Sea. The equatorial system is characterized by lower POC flux, consistent with a higher extent of $\mathrm{C}$ recycling associated with a food web dominated by smaller plankton and lower $\mathrm{C} /{ }^{234} \mathrm{Th}$ as noted earlier.

\section{Summary and recommendations}

There has been considerable expansion in the use of ${ }^{234} \mathrm{Th}$ and its ratio to POC as a C flux tracer since the first measurement of ${ }^{234} \mathrm{Th}$ in the ocean 35 years ago. Single ${ }^{234}$ Th activity profiles coupled with a few filters for POC and ${ }^{234} \mathrm{Th}$ have been superseded by programs with hundreds of ${ }^{234} \mathrm{Th}$ measurements per cruise and more sophisticated methods for $\mathrm{C} /{ }^{234} \mathrm{Th}$. Arguably, one of the largest uncertainties in the application of this approach is the correct determination of $\mathrm{C} /{ }^{234} \mathrm{Th}$ on particles that are representative of the sinking flux. Differences in $\mathrm{C} /{ }^{234} \mathrm{Th}$ are methods-related, as well as varying regionally, temporally and with depth, making it difficult to compare studies. No single process or model can account for the wide range in $\mathrm{C} /{ }^{234} \mathrm{Th}$ observations, and multiple processes are likely to play a role. Nonetheless, this does not mean the ${ }^{234} \mathrm{Th}$ approach cannot be used as an empirical flux tool. The ${ }^{234} \mathrm{Th}$ flux approach would fail if we are missing a component of the export flux that has both different $\mathrm{C} /{ }^{234} \mathrm{Th}$, and on a flux weighted basis, accounts for a significant fraction of POC export. Many of the data thus far, suggest little difference in $\mathrm{C} /{ }^{234} \mathrm{Th}$ between particles collected via pumps or traps (Fig. 4c), or by sinking velocity (Fig. 8).

Since the local plankton community influences both particle surface properties and solution ligand characteristics, regional and depth dependent fractionation of $\mathrm{C} /{ }^{234} \mathrm{Th}$ is the norm. Using single sampling methods we see regional $\mathrm{C} /{ }^{234} \mathrm{Th}$ differences and generally a constant or increasing $\mathrm{C} /{ }^{234} \mathrm{Th}$ with increasing particle size. We also see decreasing $\mathrm{C} /{ }^{234} \mathrm{Th}$ with depth. Thus, choosing $\mathrm{C} /{ }^{234} \mathrm{Th}$ at depths corresponding to the depth of export is critical. Moreover, $\mathrm{C} / \mathrm{Th}$ variability is in many cases smaller at depth, thus reducing uncertainties when applying this method.

We can currently assess $\mathrm{C} /{ }^{234} \mathrm{Th}$ variability and, by default, uncertainty by comparing $\mathrm{C} /{ }^{234} \mathrm{Th}$ ratios at a single depth and time using different particle sampling methods. This sets upper and lower limits on $\mathrm{C}$ export and typically is a smaller range in total variability than the complete range in $\mathrm{C} /{ }^{234} \mathrm{Th}$ variability found between all regions, depths and methods. Comparisons with independent methods for $\mathrm{C}$ flux can be used to argue that within a factor of $2-3$, the ${ }^{234}$ Th-derived 
fluxes agree with other indices of $\mathrm{C}$ export. However there are few cases where such $\mathrm{C}$ balances have been calculated over appropriate temporal and spatial scales.

There are inherently large uncertainties in determining C flux by mass balance approaches related to the lack of proper constraints on physical transport and other exchange mechanisms. Physical processes tend to make less difference in the ${ }^{234} \mathrm{Th}$ activity balance in the open ocean under most settings, such that ${ }^{234} \mathrm{Th}$ fluxes are determined by the magnitude of the ${ }^{234} \mathrm{Th}:{ }^{238} \mathrm{U}$ activity balance while physical transport has little effect on ${ }^{234} \mathrm{Th}$ fluxes (Savoye et al., 2006this volume). At present, ocean science in general is limited by significant uncertainties in our ability to make indirect $\mathrm{C}$ flux estimates, due to large uncertainties in quantifying air-sea gas exchange, horizontal transport rates and the relative magnitude of downward mixing of DOC and sinking POC. These limitations and related questions point to the need for the continued study of ${ }^{234} \mathrm{Th}$ as a particle flux tracer.

We are left with an imperfect tool, though one with advantages over other tracers and flux methods. We recommend some basic standardization of methods, to allow for an improved use of this approach and better intercomparison between studies. At a minimum, along with total ${ }^{234} \mathrm{Th}$ activity data and an appropriate flux model (Savoye et al., 2006-this volume), one should measure $\mathrm{C} /{ }^{234} \mathrm{Th}$ (or other elemental ratios) below the mixed layer at the depth where export is to be quantified. Many examples exist of decreasing $\mathrm{C} /{ }^{234} \mathrm{Th}$ with depth, so applying a shallow $\mathrm{C} /{ }^{234} \mathrm{Th}$ ratio to determine flux at depth is not appropriate. Application of the method to a standard depth of $100 \mathrm{~m}$ would be useful for more direct comparison between studies (though there may be good reason to be sampling other depths as well). Secondly, given the discrepancy between bottle and pump estimates of POC and the advantage of having size-fractionated data, studies that include at least the determination of $\mathrm{C} /{ }^{234} \mathrm{Th}$ on a $\sim 1.0 \mu \mathrm{m}$ filter and $53 \mu \mathrm{m}$ screen are to be encouraged. The larger particle $\mathrm{C} /{ }^{234} \mathrm{Th}$ ratios are generally more similar to ratios measured in traps and some standardization would be helpful for comparisons between different studies. Detailed size fractionated data will also allow us to validate aggregation models. Large volume sampling required for this work more likely ensures that we have captured the rarer large particles, regardless. Note finally that while a GFF filter with a nominal pore size of $0.7 \mu \mathrm{m}$ would have advantages for sampling smaller and sometimes abundant biotic particles, the ${ }^{234} \mathrm{Th}$ beta background for a GFF filter is too high for practical use, hence the recommended use of $1 \mu \mathrm{m}$ quartz fiber filters that can be easily analyzed for both POC and ${ }^{234} \mathrm{Th}$.

On a more basic level, given these potential sample collection biases, every effort should be made to make both $\mathrm{C}$ and ${ }^{234} \mathrm{Th}$ analyses on the same particle sample, as opposed to two samples or filters collected independently. Multiple ${ }^{234} \mathrm{Th}$ profiles and $\mathrm{C} /{ }^{234} \mathrm{Th}$ sampled during the course of a longer observation period are recommended, to allow for better ${ }^{234} \mathrm{Th}$ flux modeling and to determine if there are temporal variations in $\mathrm{C} /{ }^{234} \mathrm{Th}$ that are independent from changes in the ${ }^{234} \mathrm{Th}$ activity balance. This type of intensive sampling protocol, including Lagrangian time series studies, is now possible given improved and easier methods for measuring total ${ }^{234} \mathrm{Th}$ (Rutgers van der Loeff et al., 2006-this volume). While analytical methods are not the focus of this review, it is clear that better calibration of particulate ${ }^{234} \mathrm{Th}$ methods and intercomparisons of both particulate ${ }^{234} \mathrm{Th}$ and POC methods are warranted.

New collection devices such as the NBST, SPLITT and Settling Velocity Traps are promising, as they are designed to better separate particles based upon their settling properties. Early results from these new devices suggest that $\mathrm{C} /{ }^{234} \mathrm{Th}$ may be a factor of two or more higher in truly settling materials (NBST and SPLITT) versus both standard traps and from pump filters, though in one study with the Settling Velocity Trap, $\mathrm{C} /{ }^{234} \mathrm{Th}$ values observed in all particle collection methods were similar. Standard cylindrical traps can be informative, particularly if it can be shown that traps are not sorting particles or that other artifacts (swimmers and resolubilization) are minimal. More comparisons of collection devices are needed.

The future of the ${ }^{234} \mathrm{Th}$ flux approach necessitates more extensive time series analyses of total ${ }^{234} \mathrm{Th}$ activities in combination with the collection of representative samples of sinking particles for $\mathrm{C} /{ }^{234} \mathrm{Th}$. Models and speciation studies to predict $\mathrm{C} /{ }^{234} \mathrm{Th}$ variability will help considerably in increasing our understanding of how changes in local biogeochemistry can impact the $\mathrm{C} /{ }^{234} \mathrm{Th}$ ratio. This information will greatly assist in our choosing appropriate particle sampling methods. At present, the ${ }^{234} \mathrm{Th}$ flux approach has already advanced our understanding of the magnitude and controls of particle export in the ocean. With improved methods and sampling, proper application of flux models, and a better understanding of particulate $\mathrm{C} /{ }^{234} \mathrm{Th}$ variability and causes thereof, we can expect the utility of this tracer to increase, not just for its application for surface ocean $\mathrm{C}$ fluxes, but to other elements and to processes in deeper waters and in other settings. 


\section{Acknowledgements}

This material was first presented at the FATE (Future Applications of Thorium in the Environment) conference held in August 2004 at WHOI and supported by the U.S. NSF Chemical Oceanography Program (OCE 0354757) in conjunction with the Scientific Committee for Oceanographic Research (SCOR Working Group \#116). Editorial handling by R. Anderson and two reviewers, L. Miller and R. Turnewitsch, is greatly appreciated. Individuals and science efforts discussed herein were supported by many national science programs, including the U.S. National Science Foundation and U.S. Department of Energy. The International Atomic Energy Agency is grateful for the support provided to its Marine Environmental Laboratory by the Government of the Principality of Monaco. T.T. acknowledges support from the Australian Antarctic Science Program. K.B. was supported in part by a WHOI Ocean Life Institute Fellowship.

\section{References}

Alldredge, A.L., Gotschalk, C.C., 1989. Direct observations of the mass flocculation of diatom blooms: characteristics, settling velocities, and formation of diatom aggregates. Deep-Sea Research 36 (2), 159-171.

Amiel, D., Cochran, J.K., Hirschberg, D.J., 2002. ${ }^{234} \mathrm{Th} /{ }^{238} \mathrm{U}$ disequilibrium as an indicator of the seasonal export flux of particulate organic carbon in the North Water. Deep-Sea Research. Part 2. Topical Studies In Oceanography 49, 5191-5209.

Antia, 2005. Particle-associated dissolved elemental fluxes: revising the stochiometry of mixed layer export. Biogeosciences Discussions 2, 275-302.

Asper, V.A., 1987. Measuring the flux and sinking speed of marine snow aggregates. Deep-Sea Research. Part 1. Oceanographic Research Papers 34, 1-17.

Bacon, M.P., Cochran, J.K., Hirschberg, D., Hammar, T.R., Fleer, A.P., 1996. Export flux of carbon at the equator during the EqPac timeseries cruises estimated from ${ }^{234} \mathrm{Th}$ measurements. Deep-Sea Research. Part 2. Topical Studies In Oceanography 43, 1133-1154.

Bender, M., Ducklow, H., Kiddon, J., Marra, J., Martin, J., 1992. The carbon balance during the 1989 spring bloom in the North Atlantic Ocean, $47^{\circ} \mathrm{N}, 20^{\circ} \mathrm{W}$. Deep-Sea Research. Part 1. Oceanographic Research Papers 39 (10), 1707-1725.

Benitez-Nelson, C.R., Charette, M.A., 2004. Uncertainty versus variability in upper ocean carbon flux estimates. Limnology and Oceanography 49 (4), 1218-1220.

Benitez-Nelson, C., Buesseler, K.O., Crossin, G., 2000. Upper ocean carbon export, horizontal transport, and vertical eddy diffusivity in the southwestern Gulf of Maine. Continental Shelf Research 20, 707-736.

Benitez-Nelson, C., Buesseler, K.O., Karl, D., Andrews, J., 2001. A time-series study of particular matter export in the North Pacific subtropical gyre based upon ${ }^{234} \mathrm{Th}:{ }^{238} \mathrm{U}$ disequilibrium. Deep-Sea Research 48 (12), 2595-2611.
Bhat, S.G., Krishnaswamy, S.K., Lal, D., Rama, D., Moore, W.S. 1969. ${ }^{234} \mathrm{Th} /{ }^{238} \mathrm{U}$ ratios in the ocean. Earth and Planetary Science Letters 5, 483-491.

Bishop, J.K.B., Ketten, D.R., Edmond, J.M., 1978. The chemistry, biology, and vertical flux of particulate matter from the upper 400 $\mathrm{m}$ of the Cape Basin in the southeast Atlantic Ocean. Deep-Sea Research 25, 1121-1161.

Buesseler, K.O., 1991. Do upper-ocean sediment traps provide an accurate record of particle flux? Nature 353, 420-423.

Buesseler, K.O., 1998. The decoupling of production and particulate export in the surface ocean. Global Biogeochemical Cycles 12 (2), $297-310$

Buesseler, K.O., Bacon, M.P., Cochran, J.K., Livingston, H.D., 1992. Carbon and nitrogen export during the JGOFS North Atlantic Bloom Experiment estimated from ${ }^{234} \mathrm{Th}:{ }^{238} \mathrm{U}$ disequilibria. Deep-Sea Research. Part 1. Oceanographic Research Papers 39 (7-8), 1115-1137.

Buesseler, K.O., Andrews, J.A., Hartman, M.C., Belastock, R., Chai, F., 1995. Regional estimates of the export flux of particulate organic carbon derived from thorium-234 during the JGOFS EqPac program. Deep-Sea Research. Part 2. Topical Studies In Oceanography 42 (2-3), 777-804.

Buesseler, K.O., Bauer, J., Chen, R., Eglinton, T., Gustafsson, Ö., Landing, W., Mopper, K., Moran, S.B., Santschi, P., Vernon Clark, R., Wells, M., 1996. An intercomparison of cross-flow filtration techniques used for sampling marine colloids: overview and organic carbon results. Marine Chemistry 55 (1-2), 1-32.

Buesseler, K.O., Ball, L., Andrews, J., Benitez-Nelson, C., Belastock, R., Chai, F., Chao, Y., 1998. Upper ocean export of particulate organic carbon in the Arabian Sea derived from thorium-234. Deep-Sea Research. Part 2. Topical Studies In Oceanography 45 (10-11), 2461-2487.

Buesseler, K.O., Steinberg, D.K., Michaels, A.F., Johnson, R.J., Andrews, J.E., Valdes, J.R., Price, J.F., 2000. A comparison of the quantity and quality of material caught in a neutrally buoyant versus surface-tethered sediment trap. Deep-Sea Research. Part 1. Oceanographic Research Papers 47, 277-294.

Buesseler, K.O., Ball, L., Andrews, J., Cochran, J.K., Hirschberg, D.J., Bacon, M.P., Fleer, A., Brzezinski, M., 2001. Upper ocean export of particulate organic carbon and biogenic silica in the Southern Ocean along $170^{\circ}$ W. Deep-Sea Research. Part 2. Topical Studies In Oceanography 48, 4275-4297.

Buesseler, K.O., Andrews, J.E., Pike, S., Charette, M.A., Goldson, L.E., Brzezinski, M.A., Lance, V.P., 2005. Particle export during the Southern Ocean Iron Experiment (SOFeX). Limnology and Oceanography 50, 311-327.

Burd, A., Jackson, G.A., 1997. Predicting particle coagulation and sedimentation rates for a pulsed input. Journal of Geophysical Research 102 (C5), 10545-10562. doi:10.1029/ 96JC0359210545-10561.

Burd, A.B., Moran, S.B., Jackson, G.A., 2000. A coupled adsorptionaggregation model of the $\mathrm{POC} /{ }^{234} \mathrm{Th}$ ratio of marine particles. Deep-Sea Research. Part 1. Oceanographic Research Papers 47, $103-120$.

Charette, M.A., Moran, S.B., 1999. Rates of particle scavenging and particulate organic carbon export estimated using ${ }^{234} \mathrm{Th}$ as a tracer in the subtropical and equatorial Atlantic Ocean. Deep-Sea Research. Part 2. Topical Studies In Oceanography 46, 885-906.

Charette, M.A., Moran, S.B., Bishop, J.K.B., 1999. ${ }^{234}$ Th as a tracer of particulate organic carbon export in the subarctic Northeast Pacific Ocean. Deep-Sea Research. Part 2. Topical Studies In Oceanography 46 (11-12), 2833-2861. 
Coale, K.H., 1990. Labyrinth of doom: a device to minimize the "swimmer" component in sediment trap collections. Limnology and Oceanography 35 (6), 1376-1381.

Coale, K.H., Bruland, K.W., 1985. ${ }^{234} \mathrm{Th}:{ }^{238} \mathrm{U}$ disequilibria within the California Current. Limnology and Oceanography 30 (1), $22-33$.

Coale, K.H., Bruland, K.W., 1987. Oceanic stratified euphotic zone as elucidated by ${ }^{234} \mathrm{Th}:{ }^{238} \mathrm{U}$ disequilibria. Limnology and Oceanography 32 (1), 189-200.

Cochran, J.K., Buesseler, K.O., Bacon, M.P., Wang, H.W., Hirschberg, D.J., Ball, L., Andrews, J., Crossin, G., Fleer, A., 2000. Short-lived thorium isotopes $\left({ }^{234} \mathrm{Th},{ }^{228} \mathrm{Th}\right)$ as indicators of POC export and particle cycling in the Ross Sea, Southern Ocean. Deep-Sea Research. Part 2. Topical Studies In Oceanography 47 (15-16), 3451-3490.

Cochran, J.K., Miquel, J.C., Fowler, S.W., Gasser, B., Szlosek, J., Rodriguez-Ybaena, A., Hirschberg, D.J., Stewart, G., Masque, P., 2004. MEDFLUX: relationships among ballast, particulate organic carbon and ${ }^{234} \mathrm{Th}$ activities and fluxes in the upper water column. ASLO/TOS Ocean Sciences Conference, Honolulu, Hawaii, p. 30.

Collier, R., Dymond, J., Honjo, S., Manganini, S., Francois, R., Dunbar, R., 2000. The vertical flux of biogenic and lithogenic material in the Ross Sea: moored sediment trap observations 1996-1998. Deep-Sea Research. Part 2. Topical Studies In Oceanography 47 (15-16), 3491-3520.

Coppola, L., Roy-Barman, M., Wassmann, P., Mulsow, S., Jeandel, C., 2002. Calibration of sediment traps and particulate organic carbon export using ${ }^{234} \mathrm{Th}$ in the Barents Sea. Marine Chemistry $80,11-26$.

Dunne, J.P., Murray, J.W., Young, J., Balistrieri, L.S., Bishop, J., 1997. ${ }^{234} \mathrm{Th}$ and particle cycling in the central equatorial Pacific. Deep-Sea Research. Part 2. Topical Studies In Oceanography 44 (9-10), 2049-2083.

Eppley, R.W., 1989. New production: history, methods, problems. In: Berger, W.H., Smetacek, V.S., Wefer, G. (Eds.), Productivity of the Ocean: Present and Past. Wiley, New York, pp. 85-97.

Feely, R.A., Wanninkhof, R., Cosca, C.E., Murphy, P.P., Lamb, M.F., Steckley, M.D., 1995. $\mathrm{CO}_{2}$ distributions in the equatorial Pacific during the 1991-92 ENSO event. Deep-Sea Research. Part 2. Topical Studies In Oceanography 42 (2-3), 365-386.

Fisher, N.S., Teyssie, J.-L., Krishnaswami, S., Baskaran, M., 1987. Accumulation of $\mathrm{Th}, \mathrm{Pb}, \mathrm{U}$ and $\mathrm{Ra}$ in marine phytoplankton and its geochemical significance. Limnology and Oceanography 32, $131-142$.

Fleisher, M.Q., Anderson, R.F., 2003. Assessing the collection efficiency of Ross Sea sediment traps using ${ }^{230} \mathrm{Th}$ and ${ }^{231} \mathrm{~Pa}$. DeepSea Research. Part 2. Topical Studies In Oceanography 50 (3-4), $693-712$.

Fowler, S.W., Knauer, G.A., 1986. Role of large particles in the transport of elements and organic compounds through the oceanic water column. Progress in Oceanography 16, 147-194.

Gardner, W.D., 2000. Sediment trap sampling in surface waters. In: Hanson, R.B., Ducklow, H.W., Field, J.G. (Eds.), The Changing Ocean Carbon Cycle: A Midterm Synthesis of the Joint Global Ocean Flux Study. Cambridge University Press, pp. 240-281.

Gardner, W.D., Hinga, K.R., Marra, J., 1983. Observations on the degradation of biogenic material in the deep ocean with implications on the accuracy of sediment trap fluxes. Journal of Marine Research 41, 195-214.

Gardner, W.D., Richardson, M.J., Smith Jr., W.O., 2000. Seasonal patterns of water column particulate organic carbon and fluxes in the Ross Sea, Antarctica. Deep-Sea Research. Part 2. Topical Studies In Oceanography 47 (15-16), 3423-3449.

Gardner, W.D., Richardson, M.J., Carlson, C.A., Hansell, D.A., Mishonov, A.V., 2003. Determining true particulate organic carbon: bottles, pumps and methodologies. Deep-Sea Research. Part 2. Topical Studies In Oceanography 50 (3-4), 655-692.

Giddings, J.C., 1985. A system based on split-flow lateral-transport thin (SPLITT) separation cells for rapid and continuous particle fractionation. Separation Science and Technology 20, 749-768.

Goldberg, E.D., 1954. Marine chemistry: 1. Chemical scavengers of the sea. Journal of Geology 62, 249-265.

Guo, L., Santschi, P.H., Baskaran, M., 1997. Interaction of thorium isotopes with colloidal organic matter in oceanic environments. Colloids and Surfaces. A, Physicochemical and Engineering Aspects 120, 255-272.

Guo, L., Hung, C.-C., Santschi, P.H., Walsh, I.D., 2002a. ${ }^{234}$ Th scavenging and its relationship to acid polysaccharide abundance in the Gulf of Mexico. Marine Chemistry 78, 103-119.

Guo, L.D., Chen, M., Gueguen, C., 2002b. Control of Pa/Th ratio by particulate chemical composition in the ocean. Geophysical Research Letters 29 (20), 1961. doi:10.1029/2002GL015666.

Gust, G., Bowles, W., Giordano, S., Huettel, M., 1996. Particle accumulation in a cylindrical sediment trap under laminar and turbulent steady flow: an experimental approach. Aquatic Sciences 58, 297-326.

Gustafsson, Ö., Gschwend, P.M., Buesseler, K.O., 1997a. Using ${ }^{234} \mathrm{Th}$ disequilibria to estimate the vertical removal rates of polycyclic aromatic hydrocarbons from the surface ocean. Marine Chemistry $57,11-23$.

Gustafsson, Ö., Gschwend, P.M., Buesseler, K.O., 1997b. Settling removal rates of PCBs into the northwestern Atlantic derived from ${ }^{238} \mathrm{U}-{ }^{234} \mathrm{Th}$ disequilibria. Environmental Science and Technology $31,3544-3550$.

Gustafsson, Ö., Widerlund, A., Andersson, P., Ingri, J., Roos, P., 2000a. Colloid dynamics and transport of major elements through a boreal river-brackish bay mixing zone. Marine Chemistry 71 , $1-21$.

Gustafsson, Ö., Duker, A., Larsson, J., Andersson, P., Ingri, J., 2000 b. Functional separation of colloids and gravitoids in surface waters based on differential settling velocity: coupled cross-flow filtration-split flow thin cell fractionation (CFF-SPLITT). Limnology and Oceanography 45, 1731-1742.

Gustafsson, Ö., Andersson, P., Roos, P., Kukulska, Z., Broman, D., Larsson, U., Hajdu, S., Ingri, J., 2004. Evaluation of the collection efficiency of upper ocean sub-photic-layer sediment traps: a 24-month in situ calibration in the open Baltic Sea using ${ }^{234} \mathrm{Th}$. Limnology and Oceanography: Methods 2, 62-74.

Gustafsson, ø., Larsson, J., Andersson, P., Johan Ingri, J., 2006. The $\mathrm{POC} /{ }^{234} \mathrm{Th}$ ratio of settling particles isolated using split flow-thin cell fractionation (SPLITT). Marine Chemistry 100, 314-322 (this volume).

Hung, C.-C., Guo, L.D., Roberts, K.A., Santschi, P.H., 2004. Upper ocean carbon flux determined by size-fractionated ${ }^{234} \mathrm{Th}$ data and sediment traps in the Gulf of Mexico. Geochemical Journal 38 (6), $601-611$.

Jackson, G.A., 1995. Comparing observed changes in particle size spectra with those predicted using coagulation theory. Deep-Sea Research. Part 2. Topical Studies In Oceanography 42 (1), $159-184$.

Lampitt, R.S., Sanders, R.J., Boorman, B., Brown, L., Guyard, P.H., Leaute, F.J., Popova, E.E., Saw, K.A., Turnewitsch, R., Zubkov, M.V., 2004. Particulate export in the northeast Atlantic: an inte- 
grated attack using production rates, tracers and a novel drifting sediment trap. ASLO/TOS Ocean Research Conference, Honolulu, Hawaii, p. 87.

Landry, M.R., et al., 1997. Iron and grazing constraints on primary production in the central equatorial Pacific: an EqPac synthesis. Limnology and Oceanography 42, 405-418.

Lee, B.G., Fisher, N.S., 1992. Decomposition and release of elements from zooplankton debris. Marine Ecology. Progress Series 88, $117-128$.

Lee, T., Barg, E., Lal, D., Azam, F., 1993. Bacterial scavenging of ${ }^{234} \mathrm{Th}$ in surface ocean waters. Marine Ecology. Progress Series 96, 109-116.

Liu, Z., Stewart, G., Cochran, J.K., Lee, C., Armstrong, R.A., Hirschberg, D.J., Gasser, B., Miquel, J.-C., 2005. Why do POC concentrations measured using Niskin bottle collections differ from those using in situ pumps? Deep-Sea Research. Part 1. Oceanographic Research Papers 52, 1324-1344.

Lochte, K., Ducklow, H.W., Fasham, M.J.R., Stienen, C., 1993. Plankton succession and carbon cycling at $47^{\circ} \mathrm{N} 20^{\circ} \mathrm{W}$ during the JGOFS North Atlantic Bloom Experiment. Deep-Sea Research. Part 2. Topical Studies In Oceanography 40 (1-2), $91-114$.

Mang, J., Quay, P.D., 1997. The total organic carbon export rate based on ${ }^{13} \mathrm{C}$ and ${ }^{12} \mathrm{C}$ of DIC budgets in the equatorial Pacific Ocean. Deep-Sea Research. Part 2. Topical Studies In Oceanography 44, 2163-2190.

Martin, J.H., Fitzwater, S.E., Gordon, R.M., Hunter, S.N., Tanner, S.J., 1993. Iron, primary production and carbon-nitrogen flux studies during the JGOFS North Atlantic Bloom Experiment. Deep-Sea Research. Part 2. Topical Studies In Oceanography 40 $(1-2), 115-134$.

Marty, J.-C., 2002. The DYFAMED time-series program (FrenchJGOFS). Deep-Sea Research. Part 2. Topical Studies In Oceanography 49, $1963-1964$.

McCarthy, J.J., Garside, C., Nevins, J.L., 1996. New production along $140^{\circ} \mathrm{W}$ in the equatorial Pacific during and following the $1992 \mathrm{El}$ Niño event. Deep-Sea Research. Part 2. Topical Studies In Oceanography 43 (4-6), 1065-1093.

Moran, S.B., Buesseler, K.O., 1992. Short residence time of colloids in the upper ocean estimated from ${ }^{238} \mathrm{U}^{234} \mathrm{Th}$ disequilibria. Nature 359, 221-223.

Moran, S.B., Charette, M.A., Pike, S.M., Wicklund, C.A., 1999. Differences in seawater particulate organic carbon concentration in samples collected using small-volume and large-volume methods: the importance of DOC adsorption to the filter blank. Marine Chemistry 67, 33-42.

Moran, S.B., Weinstein, S.E., Edmonds, H.N., Smith, J.N., Kelly, R.P., Pilson, M.E.Q., Harrison, W.G., 2003. Does ${ }^{234} \mathrm{Th} /{ }^{238} \mathrm{U}$ disequilibrium provide an accurate record of the export flux of particulate organic carbon from the upper ocean? Limnology and Oceanography 48 (3), 1018-1029.

Moran, S.B., Weinstein, S.E., Edmonds, H.N., Smith, J.N., Kelly, R.P., Pilson, M.E.Q., Harrison, W.G., 2004. Rejoinder to comment: uncertainty versus variability in upper ocean carbon fluxes. Limnology and Oceanography 49 (4), 1221-1223.

Murray, J.W., Downs, J.N., Strom, S., Wei, C.-L., Jannasch, H.W., 1989. Nutrient assimilation, export production and ${ }^{234} \mathrm{Th}$ scavenging in the eastern equatorial Pacific. Deep-Sea Research 36 (10), 1471-1489.

Murray, J.W., Young, J., Newton, J., Dunne, J., Chapin, T., Paul, B., McCarthy, J.J., 1996. Export flux of particulate organic carbon from the central equatorial Pacific determined using a combined drifting trap- ${ }^{234}$ Th approach. Deep-Sea Research. Part 2. Topical Studies In Oceanography 43, 1095-1132.

Noji, T.T., Borsheim, K.Y., Rey, F., Nortvedt, R., 1999. Dissolved organic carbon associated with sinking particles can be crucial for estimates of vertical carbon flux. Sarsia 84, 129-135.

Passow, U., 2002. Transparent exopolymer particles (TEP) in aquatic environments. Progress in Oceanography 55, 287-333.

Passow, U., Alldredge, A., 1995. Aggregation of a diatom bloom in a mesocosm: the role of transparent exopolymer particles (TEP). Deep-Sea Research. Part 2. Topical Studies In Oceanography 42 (1), 99-110.

Passow, U., Alldredge, A.L., Logan, B.E., 1994. The role of particulate carbohydrate exudates in the flocculation of diatom blooms. Deep-Sea Research. Part 1. Oceanographic Research Papers 41 (2), 335-357.

Passow, U., Dunne, J., Murray, J.W., Balistrieri, L., Alldredge, A.L., 2006. Carbon to ${ }^{234} \mathrm{Th}$ ratios of marine organic matter. Marine Chemistry 100, 323-336 (this volume).

Peltzer, E.T., Hayward, N.A., 1996. Spatial and temporal variability of total organic carbon along $140^{\circ} \mathrm{W}$ in the equatorial Pacific Ocean in 1992. Deep-Sea Research. Part 2. Topical Studies In Oceanography 43 (6), 1155-1180.

Peterson, M.L., Hernes, P.J., Thoreson, D.S., Hedges, J.I., Lee, C., Wakeham, S.G., 1993. Field evaluation of a valved sediment trap designed to minimize collection of swimming animals. Limnology and Oceanography 38 (8), 1741-1761.

Quay, P., 1997. Was a carbon balance measured in the equatorial Pacific during JGOFS? Deep-Sea Research. Part 2. Topical Studies In Oceanography 44 (9-10), 1765-1781.

Quigley, M.S., Santschi, P.H., Hung, C.-C., Guo, L., Honeyman, B.D., 2002. Importance of polysaccharides for ${ }^{234} \mathrm{Th}$ complexation to marine organic matter. Limnology and Oceanography 47 , $367-377$.

Reinfelder, J.R., Fisher, N.S., 1991. The assimilation of elements ingested by marine copepods. Science 251, 794-796.

Rutgers van der Loeff, M.M., Buesseler, K.O., Bathmann, U., Hense, I., Andrews, J., 2002. Comparison of carbon and opal export rates between summer and spring bloom periods in the region of the Antarctic Polar Front, SE Atlantic. Deep-Sea Research. Part 2. Topical Studies In Oceanography 49 (18), 3849-3870.

Rutgers van der Loeff, M., Sarin, M.M., Baskaran, M., BenitezNelson, C., Buesseler, K., Charette, M., Dai, M., Gustafsson, ø., Masque, P., Morris, P., Orlandini, K., Rodriguez y Baena, A., Savoye, N., Schmidt, S., Turnewitsch, R., V-ge, I., Waples, J., 2006. A review of present techniques and methodological advances in analyzing ${ }^{234} \mathrm{Th}$ in aquatic systems. Marine Chemistry $100,190-212$ (this volume).

Santschi, P.H., Hung, C.-C., Schultz, G., Alvarado-Quiroz, N., Guo, L., Pinckney, J., Walsh, I., 2003. Control of acid polysaccharide production and ${ }^{234} \mathrm{Th}$ and POC export fluxes by marine organisms. Geophysical Research Letters 30 (2), 1044. doi:10.1029/ 2002GL016046.

Santschi, P.H., Murray, J.W., Baskaran, M., Benitez-Nelson, C.R., Guo, L.D., Hung, C.-C., Lamborg, C., Moran, S.B., Passow, U., Roy-Barman, M., 2006. Thorium speciation in seawater. Marine Chemistry 100, 250-268 (this volume).

Savoye, N., Buesseler, K.O., Cardinal, D., Dehairs, F., 2004. ${ }^{234} \mathrm{Th}$ deficit and excess in the Southern Ocean during spring 2001: particle export and mineralization. Geophysical Research Letters 31, 12301. doi:10.1029/2004GL019744.

Savoye, N., Benitez-Nelson, C., Burd, A.B., Cochran, J.K., Charette, M., Buesseler, K.O., Jackson, G., Roy-Barman, M., Schmidt, S., 
Elskens, M., 2006. ${ }^{234}$ Th sorption and export models in the water column: a review. Marine Chemistry 100, 234-249 (this volume).

Schmidt, S., Andersen, V., Belviso, S., Marty, J.-C., 2002. Strong seasonality in particle dynamics of north-western Mediterranean surface waters as revealed by ${ }^{234} \mathrm{Th} /{ }^{238} \mathrm{Th}$. Deep-Sea Research. Part 1. Oceanographic Research Papers 49, 1507-1518.

Smayda, T.R., 1970. The suspension and sinking of phytoplankton in the sea. Oceanography and Marine Biology: An Annual Review, vol. 8. 335 pp.

Snoeijs, P., Busse, S., Potapova, M., 2002. The importance of diatom cell size in community analysis. Journal of Phycology $38,265-272$.

Stanley, R.H.R., Buesseler, K.O., Manganini, S.J., Steinberg, D.K., Valdes, J.R., 2004. A comparison of major and minor elemental fluxes collected using neutrally buoyant and surface-tethered traps. Deep-Sea Research. Part 1. Oceanographic Research Papers 51, 1387-1395.

Sweeney, C., Hansell, D.A., Carlson, C.A., Codispoti, L.A., Gordon, L.I., Marra, J., Millero, F.J., Smith, W.O., Takahashi, T., 2000. Biogeochemical regimes, net community production and carbon export in the Ross Sea, Antarctica. Deep-Sea Research. Part 2. Topical Studies In Oceanography 47 (15-16), 3369-3394.

Trull, T.W., Armand, L., 2001. Insights into Southern Ocean carbon export from the del- ${ }^{13} \mathrm{C}$ of particles and dissolved inorganic carbon during the SOIREE iron fertilisation experi- ment. Deep-Sea Research. Part 2. Topical Studies In Oceanography 48 (11-12), 2655-2680.

Tsunogai, S., Minagawa, M., 1976. Vertical flux of organic materials estimated from Th-234 in the ocean. Joint Oceanographic Assembly, Edinburgh, vol. 13-24, p. 156.

Valdes, J.R., Price, J.F., 2000. A neutrally buoyant, upper ocean sediment trap. Journal of Atmospheric and Oceanographic Technology 17 (1), 62-68.

Waite, A.M., Hill, P.S., 2006. Flocculation and phytoplankton cell size can alter ${ }^{234} \mathrm{Th}$-based estimates of the vertical flux of particulate organic carbon in the sea. Marine Chemistry 100, 366-375 (this volume).

Wakeham, S.G., Hedges, J.I., Lee, C., Peterson, M.L., Hernes, P.J., 1997. Composition and fluxes of lipids through the water column and surficial sediments of the equatorial Pacific Ocean. Deep-Sea Research. Part 2. Topical Studies In Oceanography 44, 2131-2162.

Weinstein, S.E., Moran, S.B., in review. Vertical flux of particulate Al, $\mathrm{Fe}, \mathrm{Pb}$ and $\mathrm{Ba}$ from the upper ocean determined using ${ }^{234} \mathrm{Th} /{ }^{238} \mathrm{U}$ disequilibrium. Deep-Sea Research. Part 2. Topical Studies In Oceanography. 